\title{
Chemical Pathways for the Formation of Ammonia in Hanford Wastes
}

L. M. Stock

L. R. Pederson

December 1997

\section{MACTR \\ MASTER}

Prepared for

the U. S. Department of Energy

under Contract DE-AC06-76RLO 1830

Pacific Northwest National Laboratory

Richland, Washington 99352 


\section{DISCLAIMER}

This report was prepared as an account of work sponsored by an agency of the United States Government. Neither the United States Government nor any agency thereof, nor any of their employees, make any warranty, express or implied, or assumes any legal liability or responsibility for the accuracy, completeness, or usefulness of any information, apparatus, product, or process disclosed, or represents that its use would not infringe privately owned rights. Reference herein to any specific commercial product, process, or service by trade name, trademark, manufacturer, or otherwise does not necessarily constitute or imply its endorsement, recommendation, or favoring by the United States Government or any agency thereof. The views and opinions of authors expressed herein do not necessarily state or reflect those of the United States Government or any agency thereof. 


\section{DISCLAIMER}

Portions of this document may be illegible electronic image products. Images are produced from the best available original document. 


\section{Summary}

This report reviews chemical reactions leading to the formation of ammonia in Hanford wastes. The general features of the chemistry of the organic compounds in the Hanford wastes are briefly outlined. The radiolytic and thermal free radical reactions that are responsible for the initiation and propagation of the oxidative degradation reactions of the nitrogen-containing complexants, trisodium HEDTA and tetrasodium EDTA, are outlined. In addition, the roles played by three different ionic reaction pathways for the oxidation of the same compounds and their degradation products are described as a prelude to the discussion of the formation of ammonia. The reaction pathways postulated for its formation are based on tank observations, laboratory studies with simulated and actual wastes, and the review of the scientific literature. Ammonia derives from the reduction of nitrite ion (most important), from the conversion of organic nitrogen in the complexants and their degradation products, and from radiolytic reactions of nitrous oxide and nitrogen (least important).

Reduction of nitrite ions is believed to be the most important source of ammonia. Whether by radiolytic or thermal routes, nitrite reduction reactions proceed through nitrogen dioxide, nitric oxide, the nitrosyl anion, and the hyponitrite anion. Nitrite ion is also converted into hydroxylamine, another important intermediate on the pathway to form ammonia. These reaction pathways additionally result in the formation of nitrous oxide and molecular nitrogen, whereas hydrogen formation is produced in a separate reaction sequence.

The oxidative degradation of trisodium HEDTA and tetrasodium EDTA also yields ammonia and other nitrogenous gases. The complexants react with nitric oxide and nitrogen dioxide to produce oxidized compounds that subsequently undergo hydrolysis, eventually liberating ammonia. Amides and nitriles are intermediates in these long reaction sequences. The direct reaction of hydrogen with nitrous oxide and nitrogen can account for only negligible quantities of ammonia in Hanford tanks. Thermal reactions require high temperatures $\left(>400^{\circ} \mathrm{C}\right)$, high pressures, and the presence of catalysts to proceed at significant rates. Similarly, radiolytic yields for direct reactions of hydrogen with nitrogen and nitrous oxide under tank conditions are expected to be very small.

Oxygen can substantially alter the yields of nitrogenous gases. Two principal pathways have been identified. Oxygen intercepts radicals produced in thermal and radiolytic reactions that would otherwise eventually result in the formation of nitrogen, nitrous oxide, and ammonia. Oxygen also reacts directly with complexants and intermediates to yield oxalate ion. The hydrogen yield is often increased in the presence of oxygen. 


\section{Contents}

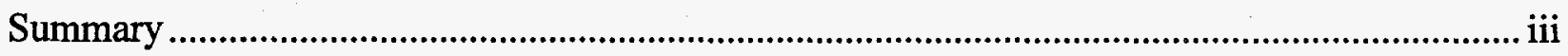

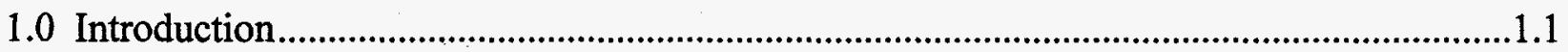

2.0 General Features of Organic Reactions in Hanford Wastes...................................................

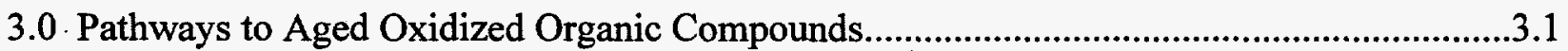

3.1 Initiation and Propagation of Complexant Reactions with Radicals ..............................3.3

3.1.1 Initiation and Propagation Reactions for Conversion of HEDTA to ED3A.....3.3

3.1.2 Propagation Reactions for the Conversion of HEDTA to ED3A ......................3.4

3.1.3 Initiation and Propagation Reactions for Conversion of EDTA to NTA

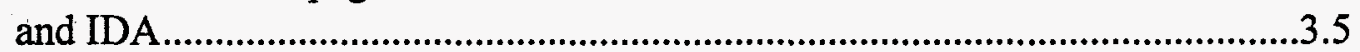

3.1.4 Propagation Reactions for EDTA to NTA and IDA ..........................................

3.2 Base-Catalyzed Ionic Oxidation Reactions....................................................................

3.3 Ionic Oxidation Reactions Induced by the Nitrite-Aluminate Complex............................

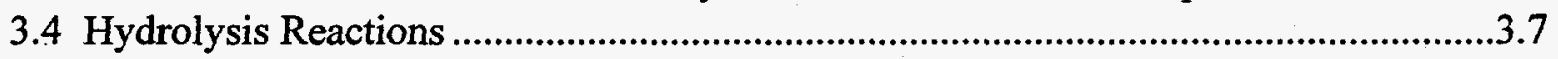

4.0 The Reduction Pathway to Gaseous Products ......................................................................

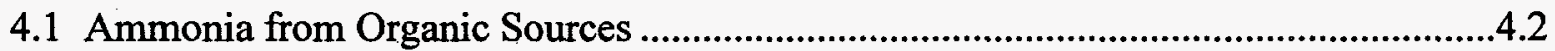

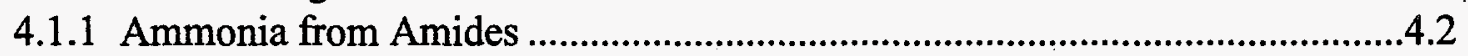

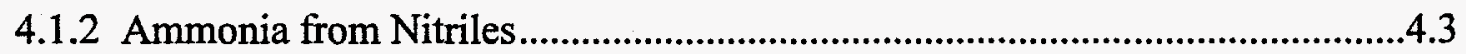

4.2 Ammonia from Inorganic Sources...............................................................................4.4

4.2.1 Ammonia from Inorganic Sources with No Organic Compounds Present........4.5

4.2.2 Ammonia from Hydroxylamine.......................................................................... 4.6

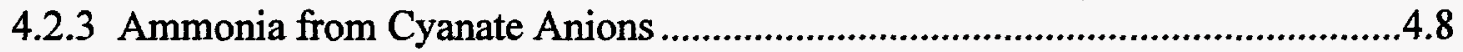

5.0 Formation of Nitrous Oxide, Nitrogen, and Hydrogen .............................................................5.1

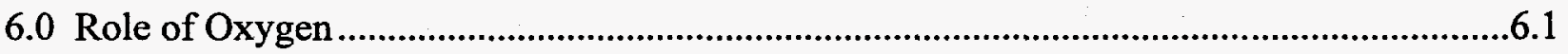

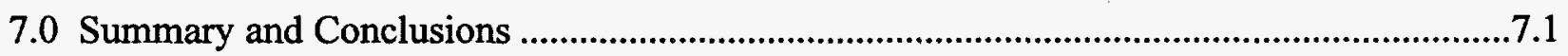

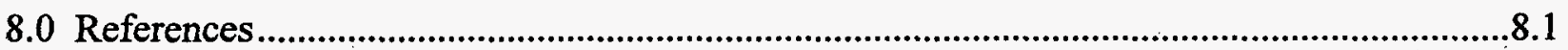




\section{Figures}

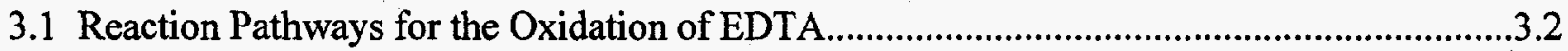

Tables

6.1 Decomposition of HEDTA in Simulated Hanford Waste at $120^{\circ} \mathrm{C}, 200$ hours. 6.1 


\subsection{Introduction}

Ammonia is a pervasive constituent of wastes stored in both single-shell tanks (SSTs) and double-shell tanks (DSTs) at Hanford. Ammonia contributes to the flammability hazard in Hanford waste tanks (LANL 1994) and is also toxic at relatively low concentrations.

A product of thermal and radiolytic reactions in these wastes, ammonia is the most watersoluble of the gases that are formed (Norton and Pederson 1994, 1995). As such, larger amounts of ammonia can be retained within the wastes than other gaseous products such as hydrogen, nitrogen, and nitrous oxide. Concentrations of ammonia in the liquid phase of these tanks are small, usually less than a few tenths of a weight percent. However, because waste volumes are quite large, this translates into a substantial quantity of ammonia. For example, in Tank A-101, ${ }^{(a)}$ there are about 12,000 moles of ammonia in the nonconvecting layer and 30,000 moles of ammonia in the convecting layer (Shekarriz et al. 1997). ${ }^{(\mathbf{b})}$ Passively ventilated Tank A-101 releases about 8,000 moles of ammonia each year.

The purpose of this report is to summarize chemical mechanisms by which ammonia is formed in Hanford wastes. There are two main pathways by which ammonia is formed: (1) the conversion of nitrogen atoms originally present in complexants such as trisodium hydroxyethylethylenediaminetriacetate (sodium HEDTA) and tetrasodium ethylenediaminetetraacetic acid (sodium EDTA), and (2) the reduction of nitrite ions to ammonia by thermal and radiolytic reactions during the chemical conversions of the organic solvents and complexants. The Hanford Defined Waste (HDW) model (Agnew et al. 1995a, 1995b, 1996, 1997) provides an upper limit on the quantity of ammonia that can be produced via conversion of organic nitrogen for each tank. For example, 560,000 moles of ammonia could eventually be produced in Tank A-101 via pathway (1), a value nearly 20 times greater than the inventory of ammonia reported by Shekarriz et al. (1997) for that tank. Studies with simulants performed at the Georgia Institute of Technology and Argonne National Laboratory imply that much more ammonia is produced by pathway (2) than by pathway (1). Unfortunately, there are no accurate estimates of the amount of ammonia that can be produced by pathway (2).

This report is divided into several sections. General features of the oxidation reactions of the organic complexants, including a brief commentary on their identity and reactivity, are summarized in Section 2. The five principal organic aging reactions are given in Section 3; the reactions are partitioned into thermal and radiolytic free radical pathways as well as three different ionic reactions: the reactions of aldehydes with hydroxide ions, oxidation reactions of the organic constituents of the waste with nitrite ion driven by the aluminate ion, and the basecatalyzed hydrolysis of amides. Mechanisms considering both organic and inorganic sources for the formation of ammonia are discussed in Section 4; the closely related pathways for generation

(a) Tanks are officially numbered with the prefix 241 - followed by the tank farm designation and actual tank number. In this report the prefix is omitted, as it is in common usage.

(b) Steen FH. 1996. Waste Compatibility Results for 241-A-101 Grab Samples, Internal Memorandum 75725-96-027 to Westinghouse Hanford Company, Richland, Washington. 
of nitrous oxide and nitrogen are discussed in Section 5. Oxygen can significantly shift the product distribution away from nitrogenous gases and towards hydrogen; its role is discussed in Section 6. The principal conclusions are summarized in Section 7, and Section 8 contains the cited references. 


\subsection{General Features of Organic Reactions in Hanford Wastes}

The original organic components in the Hanford waste tanks were sodium glycolate, citrate, HEDTA; EDTA, normal paraffinic hydrocarbons (NPH) and tributyl phosphate (Webb et al. 1995). These compounds have undergone aging to more oxidized products over the years that they have been stored (Camaioni et al. 1995, 1996, 1997; Carlson 1997). Decomposition products that have been identified include sodium ethylenediaminetriacetate (ED3A), sodium nitrilotriacetate (NTA), sodium iminodiacetate (IDA), sodium ethylenediaminediacetate (EDDA), sodium oxalate, and sodium formate (Campbell et al. 1994, 1995, 1996). The energy content of the aged oxidation products is less than the energy content of the starting materials (Burger 1995), and the eventual product of the oxidative reaction sequence is sodium carbonate. Aging of the organic constituents, therefore, simultaneously reduces the total organic carbon content and the energy available upon reaction of the aged fragments with the inorganic oxidants (Camaioni et al. 1996, 1997).

The thermal and radiolytic oxidation of organic compounds in simulated Hanford wastes have been studied extensively (Ashby et al. 1992, 1993,1994; Barefield et al. 1995, 1996; Bryan et al. 1993; Bryan and Pederson 1994; Camaioni et al. 1995, 1996, 1997; Delegard 1980, 1987; Meisel et al. 1991a, 1991b, 1992, 1993, 1997). The reactivity order for thermal degradation of the complexants, which encompasses all the pathways for the decomposition of the organic constituents in the waste in the absence of radiation, has been given as (Camaioni et al. 1996, 1997):

Glycolate $>$ HEDTA $>$ citrate $>>$ EDDA $>$ EDTA, glycine, IDA, and NTA

Rates of thermal decomposition were shown to be dependent on temperature and on nitrite, hydroxide, and aluminate ion concentrations. An early study by Delegard (1987) reported that HEDTA and glycolate ions degraded thermally, producing hydrogen, nitrogen, nitrous oxide, and ammonia gases. Condensed-phase products identified were ED3A and oxalate ions from HEDTA, and oxalate ion from sodium glycolate. Ashby et al. (1994) reported that thermal aging of HEDTA ion produced ethylenediaminediacetate (EDDA), IDA, glycine, and formate ions in addition to ED3A and oxalate ions. Glycolate ion aged to produce sodium formate and oxalate. Citrate ion was shown to decompose thermally producing sodium oxalate and acetate (Ashby et al. 1994). The reaction was found to be strongly catalyzed by hydroxide ions. Barefield et al. $(1995,1996)$ provided a detailed accounting of the thermal decomposition of trisodium HEDTA in simulated waste mixtures for reaction times up to nearly one year.

Additional radiolytic pathways are available for the aging of complexants and solvents in Hanford wastes (Meisel et al. 1991a, 1991b, 1992, 1993,1997; Camaioni et al. 1995, 1996, 1997). Products of water radiolysis include the hydrated electron, hydrogen atom, hydroxide radical, hydrogen dioxide radical, and hydrogen ion (Spinks and Woods 1990). While the overall concentration of the initial radiolytic species is usually quite small, localized concentrations within a spur may be quite high, exceeding 1 mole/liter. It is the reaction of primary radiolytic species with nitrite and nitrate anions that is responsible for many of the subsequent 
chemical reactions that occur in Hanford waste tanks (Camaioni et al. 1997; Meisel et al. 1997). The hydrated electron is effectively captured by the nitrate anion, leading to the formation of nitrogen dioxide.

Hydrogen radicals are scavenged by relatively high concentrations of nitrite ions to produce nitric oxide. The reactions of the oxides of nitrogen, especially nitric oxide nitrogen dioxide, with the organic constituents in the waste are ultimately responsible for the oxidation and fragmentation of the organic constituents and, in addition, for the formation of hydrogen, ammonia, nitrous oxide, and molecular nitrogen.

The relative reactivity of complexants and their principal degradation products toward radiolytic degradation in the absence of oxygen decreases in the order (Camaioni et al 1997):

$$
\text { HEDTA }>\text { s-EDDA }=u \text {-EDDA }>\text { IDA }>\text { NTA }>\text { glycine }>\text { glycolate }>\text { EDTA }>\text { formate }>\text { citrate }=\text { acetate }
$$

The HEDTA ion reacts about 25 times more rapidly than the acetate ion, a rather modest difference. 


\subsection{Pathways to Aged Oxidized Organic Compounds}

Organic constituents are oxidized and nitrite ions reduced by both free radical and ionic pathways. Many different reactions are synergistically coupled to degrade and eventually destroy the organic compounds. The free radical reactions are initiated both radiolytically and thermally. Ionic reactions include the reaction of aldehydes with hydroxide ion, the aluminate ion-catalyzed oxidation reactions of organic molecules by nitrite ion, and hydrolysis reactions such as the base-catalyzed hydrolysis of amides. Selected features of the chemistry of EDTA and HEDTA are discussed in this section to describe the general pathways for the degradation of these substances and to provide the technical background for the subsequent discussion of the reactions leading to the formation of ammonia and other gases.

There are many individual steps in the reaction sequences that eventually convert a complexant such as HEDTA or EDTA into formate, oxalate, and carbonate ions. The complexity of the chemistry is shown in the simplified reaction path for EDTA, which omits many intermediates, in Figure 3.1. The products that are designated in bold face have been detected in tank waste (Campbell et al. 1994, 1995, 1996). Glycine has been shown to be a reaction product in laboratory work (Ashby et al. 1994; Barefield et al. 1995; Camaioni et al. 1996, 1997).

The term hydrolysis is used in this report to identify the broad array of reactions that are responsible for the transformation of reaction intermediates into alcohols, aldehydes, ketones, amides, nitriles, and carboxylates. These include the hydrolyses of organic and inorganic esters; amide hydrolyses; the related conversion reactions of nitrogen-containing orthoesters, ketals, acetals, hemiacetals; the broad family of base-catalyzed elimination reactions at carbon, nitrogen, and oxygen centers; and substitution reactions of saturated and unsaturated carbon.

Radical Reactions. The most important oxidation reactions involving complexants and solvents in Hanford wastes are initiated by atoms and radicals that are formed in radiolytic reactions. The initial products of the radiolysis of water and the inorganic salts abstract either a hydrogen atom or an electron from the organic constituents to initiate chemical transformations. The radiolytic processes have negligible activation energies. Similar reactions are initiated by the radicals that are formed by the decomposition of inorganic constituents of the wastes when they are heated. These reactions have high activation energies and proceed slowly at $50^{\circ} \mathrm{C}, \mathrm{a}$ typical tank waste temperature. There is no evidence that the organic constituents fragment homolytically to initiate radical reactions under the usual conditions of storage.

Ionic Reactions. The base-catalyzed ionic oxidation reactions of organic complexants, fragments, and solvents occur in Hanford wastes. The most important reaction of this kind is the hydroxide ion-initiated transformation of an aldehyde into a sodium carboxylate and hydrogen gas (Ashby et al. 1994; Barefield et al. 1995, 1996).

The oxidation of the organic molecules with hydroxyl groups, including citrate, glycolate, and HEDTA anions by nitrite ions promoted by the aluminate ion, has been proposed to account 


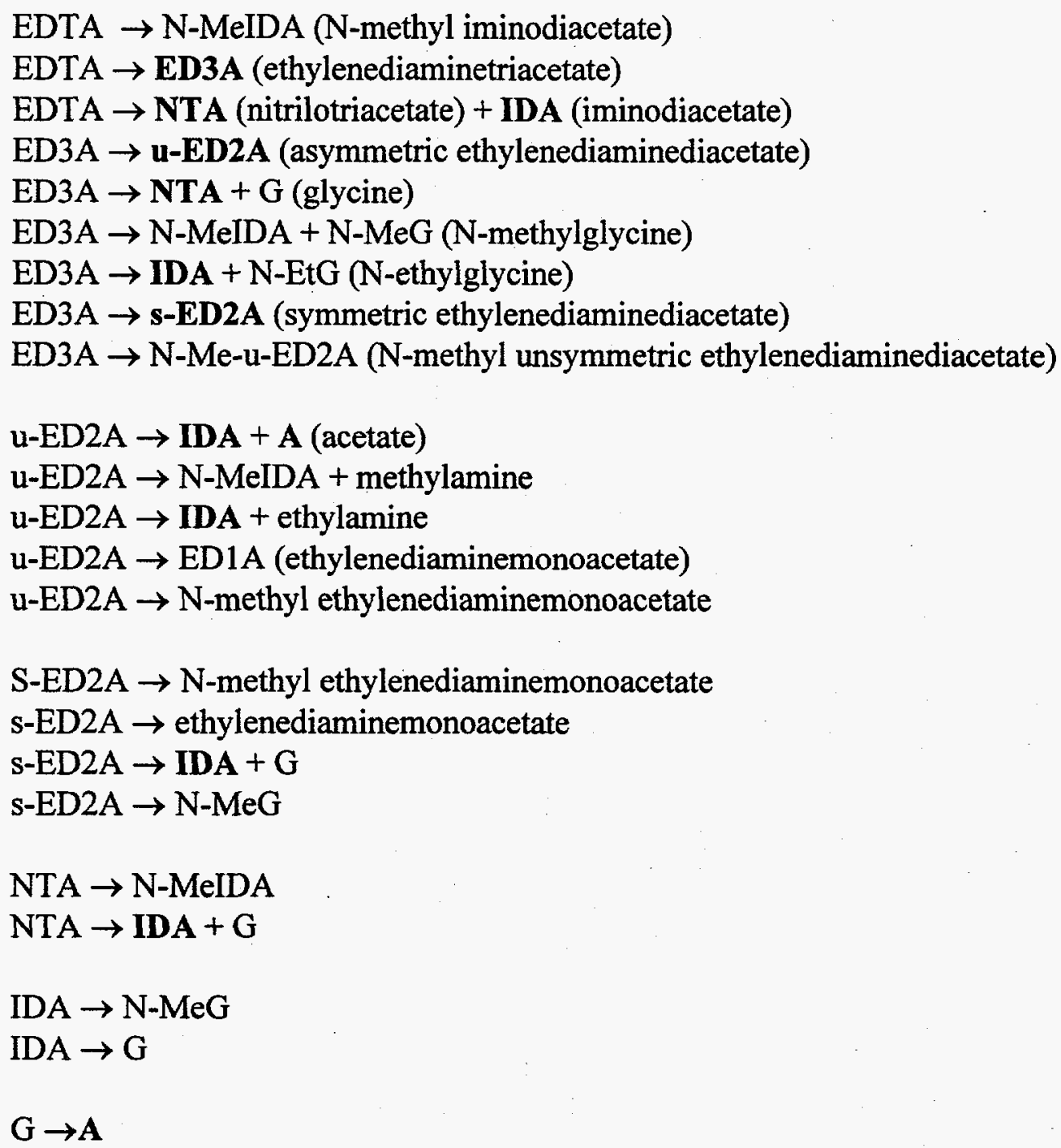

Figure 3.1. Reaction Pathways for the Oxidation of EDTA (bolded products have been identified in DST wastes by Campbell et al. [1994, 1995, 1996])

for their decomposition in the absence of radiation (Ashby et al. 1993, 1994; Barefield et al. 1995, 1996; Delegard 1980). The transfer of hydrogen from the organic constituent to the nitrito ligand is greatly facilitated by the coordination of both molecular units to the aluminate ion.

Hydrolysis reactions are also important in Hanford wastes. The amides and nitriles formed from fragmentation of complexants are hydrolyzed under the conditions of storage (Ashby et al. 1993, 1994; Barefield et al. 1995, 1996; Camaioni et al. 1997). Acetals and the analogous nitrogenous derivatives formed as intermediates on several reaction pathways are also susceptible to hydrolysis.

The rate of decomposition of organic waste components is therefore the sum of all available reaction pathways: 
Generally, these five reaction channels are independent processes, and all proceed simultaneously. Actual rates depend on the composition of the waste under consideration (concentrations of reagents in the tank, temperature, radiation dose rate, etc.). It has also been demonstrated that free radical reactions initiated by radiolytic reactions proceed at normal storage temperatures, whereas the thermally induced free radical reactions occur much more slowly under such conditions. The base-catalyzed hydrolysis reactions of amides and the reactions of hydroxide ion with aldehydes proceed quite rapidly under the typical conditions of storage. The aluminate ion-promoted hydrogen transfer reactions occur somewhat more slowly. Differences in the rates of reaction in the different phases constitute a major uncertainty at present.

\subsection{Initiation and Propagation of Complexant Reactions with Radicals}

The free radical initiation and propagation reactions for HEDTA and EDTA ion encompass many of reactions that occur in Hanford wastes. The radiolysis of EDTA and HETDA ion in simulants provides ED3A, formate, oxalate, and carbonate ions as well as NTA and IDA (Camaioni et al. 1997). The initial reaction paths for these conversions are described in this section.

\subsubsection{Initiation and Propagation Reactions for Conversion of HEDTA to ED3A}

\section{Initiation by Hydrogen Atom Abstraction}

Hydrogen atom abstraction and electron transfer reactions initiate the reaction. The abstraction of a hydrogen atom from the reactive position adjacent to the nitrogen atom is highlighted in this example since it offers a relatively direct route from HEDTA to ED3A. The first step is

$$
\mathrm{A}+\mathrm{RN}\left(\mathrm{CH}_{2} \mathrm{CO}_{2}{ }^{-}\right) \mathrm{CH}_{2} \mathrm{CH}_{2} \mathrm{OH} \rightarrow \mathrm{AH}+\mathrm{RN}\left(\mathrm{CH}_{2} \mathrm{CO}_{2}^{-}\right) \mathrm{CHCH}_{2} \mathrm{OH}
$$

where

$$
\begin{aligned}
& \mathrm{R}=\left(\mathrm{O}_{2} \mathrm{CCH}_{2}\right)_{2} \mathrm{NCH}_{2} \mathrm{CH}_{2}, \mathrm{~A}=\mathrm{H}, \mathrm{OH}, \mathrm{NO} \text {, and } \mathrm{NO}_{2} \text { and } \mathrm{AH}=\mathrm{H}_{2}, \mathrm{HOH}, \mathrm{NOH}, \\
& \quad \text { and } \mathrm{HNO}_{2}
\end{aligned}
$$

The rate constants for the reactions of hydrogen atom, hydroxyl radical and its anion, and nitrogen trioxide are known for many of the molecules present in the Hanford wastes (Buxton et al. 1988). However, the rate constants for the reactions of nitric oxide and nitrogen dioxide with these compounds have not been directly measured. 


\section{Initiation by Electron Transfer}

The electron transfer initiation reactions follow the path:

$$
\mathrm{A}+\mathrm{RN}\left(\mathrm{CH}_{2} \mathrm{CO}_{2}^{-}\right) \mathrm{CH}_{2} \mathrm{CH}_{2} \mathrm{OH} \rightarrow \mathrm{A}^{-}+\mathrm{RN}^{+}\left(\mathrm{CH}_{2} \mathrm{CO}_{2}^{-}\right) \mathrm{CH}_{2} \mathrm{CH}_{2} \mathrm{OH}
$$

where $\mathrm{R}$ and $\mathrm{A}$ have the same meaning, and $\mathrm{A}^{-}=\mathrm{OH}^{-}, \mathrm{NO}^{-}, \mathrm{NO}_{2}^{-}$. Few of the rate constants for the relevant electron transfer reactions have been measured. However, the rate constants for the decomposition of the cation radicals of certain structurally related amino acids have been recently reported (Su et al. 1997).

\subsubsection{Propagation Reactions for the Conversion of HEDTA to ED3A}

\section{Through Free Radical Formed in Reaction 3.2}

The reaction is propagated by the reaction of the radical intermediates with the array of ions and radicals in the reaction medium. Selected reaction sequences for the radical from HEDTA with four different reactive components in the reaction medium are presented. These reactions all could contribute to the eventual formation of ED3A ion, the main initial product of the oxidative fragmentation of HEDTA.

Intermediates from hydrogen atom abstraction obtained in Reaction 3.2 can react with nitric oxide, nitrogen dioxide, hydroxyl radicals, as well as with the highly abundant nitrite ion, to form new covalent bonds. The bimolecular radical reactions are presented first:

$$
\begin{aligned}
& \mathrm{RN}\left(\mathrm{CH}_{2} \mathrm{CO}_{2}^{-}\right) \mathrm{CHCH}_{2} \mathrm{OH}+\mathrm{NO} \rightarrow \mathrm{RN}\left(\mathrm{CH}_{2} \mathrm{CO}_{2}^{-}\right) \mathrm{CH}(\mathrm{NO}) \mathrm{CH}_{2} \mathrm{OH} \\
& \mathrm{RN}\left(\mathrm{CH}_{2} \mathrm{CO}_{2}^{-}\right) \mathrm{CHCH}_{2} \mathrm{OH}+\mathrm{NO}_{2} \rightarrow \mathrm{RN}\left(\mathrm{CH}_{2} \mathrm{CO}_{2}^{-}\right) \mathrm{CH}(\mathrm{ONO}) \mathrm{CH}_{2} \mathrm{OH} \\
& \mathrm{RN}\left(\mathrm{CH}_{2} \mathrm{CO}_{2}^{-}\right) \mathrm{CHCH}_{2} \mathrm{OH}+\mathrm{NO}_{2} \rightarrow \mathrm{RN}\left(\mathrm{CH}_{2} \mathrm{CO}_{2}^{-}\right) \mathrm{CH}\left(\mathrm{NO}_{2}\right) \mathrm{CH}_{2} \mathrm{OH} \\
& \mathrm{RN}\left(\mathrm{CH}_{2} \mathrm{CO}_{2}^{-}\right) \mathrm{CHCH}_{2} \mathrm{OH}+\mathrm{OH} \rightarrow \mathrm{RN}\left(\mathrm{CH}_{2} \mathrm{CO}_{2}^{-}\right) \mathrm{CH}(\mathrm{OH}) \mathrm{CH}_{2} \mathrm{OH}
\end{aligned}
$$

The reaction between the organic radical and nitrite ion (Leffler 1993) is favored by the very high concentration of nitrite ion in the reaction medium:

$$
\mathrm{RN}\left(\mathrm{CH}_{2} \mathrm{CO}_{2}^{-}\right) \mathrm{CHCH}_{2} \mathrm{OH}+\mathrm{NO}_{2}^{-} \rightarrow \mathrm{RN}\left(\mathrm{CH}_{2} \mathrm{CO}_{2}^{-}\right) \mathrm{CH}\left(\mathrm{NO}_{2}{ }^{-}\right) \mathrm{CH}_{2} \mathrm{OH}
$$

Electron transfer to an acceptor, A, provides the same product as Reaction 3.6.

$$
\mathrm{A}+\mathrm{RN}\left(\mathrm{CH}_{2} \mathrm{CO}_{2}{ }^{-}\right) \mathrm{CH}\left(\mathrm{NO}_{2}{ }^{-}\right) \mathrm{CH}_{2} \mathrm{OH} \rightarrow \mathrm{A}^{-}+\mathrm{RN}\left(\mathrm{CH}_{2} \mathrm{CO}_{2}{ }^{-}\right) \mathrm{CH}\left(\mathrm{NO}_{2}\right) \mathrm{CH}_{2} \mathrm{OH}
$$

for the group of A molecules mentioned previously.

All of the products in Reactions 3.4 to 3.9 have two electronegative atoms bonded to the carbon atom from which the hydrogen atom was abstracted. As discussed subsequently, the hydrolysis of these compounds will produce ED3A and a reactive aldehyde. The nitrogen atom in the oxidant nitrite ion has been reduced in this reaction sequence providing either hydroxylamine or hyponitrite ion as discussed subsequently in Section 4. 


\section{Through Electron Transfer Intermediate Formed in Reaction 3.3}

The fate of the electron transfer intermediate is similar and more direct. The original electron transfer product can provide the same triacetate, ED3A, and a radical $\left(\mathrm{CH}_{2} \mathrm{OH}\right)$ that converts to formaldehyde (Reaction 3.10). The charged intermediate also produces formaldehyde (Reaction 3.11).

$$
\begin{aligned}
& \mathrm{R}\left(\mathrm{CH}_{2} \mathrm{CO}_{2}^{-}\right) \mathrm{N}^{+} \mathrm{CH}_{2} \mathrm{CH}_{2} \mathrm{OH} \rightarrow \mathrm{R}\left(\mathrm{CH}_{2} \mathrm{CO}_{2}^{-}\right) \mathrm{N}^{+}=\mathrm{CH}_{2}+\mathrm{CH}_{2} \mathrm{OH} \\
& \mathrm{R}\left(\mathrm{CH}_{2} \mathrm{CO}_{2}^{-}\right) \mathrm{N}^{+}=\mathrm{CH}_{2}+\mathrm{OH}^{-} \rightarrow \mathrm{RNH}\left(\mathrm{CH}_{2} \mathrm{CO}_{2}^{-}\right)+\mathrm{CH}_{2} \mathrm{O}
\end{aligned}
$$

The end products of the hydrogen abstraction and electron transfer reactions of HEDTA are similar in the sense that both processes yield ED3A. They differ in one significant way: the electron transfer pathway favors the formation of the formate ion, whereas hydrogen atom abstraction pathway leads to the formation of both formate and oxalate ions.

\subsubsection{Initiation and Propagation Reactions for the Conversion of EDTA to NTA and IDA}

\section{Initiation by Hydrogen Atom Abstraction}

The reaction pathway for the conversion of EDTA into the anions of NTA and IDA is initiated by the abstraction of a hydrogen atom from the ethano (ethylene) group:

$$
\mathrm{A}+\mathrm{R}_{2}^{\prime} \mathrm{NCH}_{2} \mathrm{CH}_{2} \mathrm{~N}\left(\mathrm{CH}_{2} \mathrm{CO}_{2}^{-}\right)_{2} \rightarrow \mathrm{AH}+\mathrm{R}_{2}^{\prime} \mathrm{NCH}_{2} \mathrm{CHN}\left(\mathrm{CH}_{2} \mathrm{CO}_{2}^{-}\right)_{2}
$$

where $\mathrm{R}^{\prime}=\left(\mathrm{O}_{2} \mathrm{CCH}_{2}\right), \mathrm{A}=\mathrm{NO}, \mathrm{NO}_{2}$, and $\mathrm{OH}$ and $\mathrm{AH}=\mathrm{HNO}, \mathrm{HNO}_{2}$, and $\mathrm{HOH}$.

Initiation by Electron Transfer

The same reagents responsible for the hydrogen atom abstraction could initiate the reaction by electron transfer:

$$
\mathrm{A}+\mathrm{R}_{2}^{\prime} \mathrm{NCH}_{2} \mathrm{CH}_{2} \mathrm{~N}\left(\mathrm{CH}_{2} \mathrm{CO}_{2}^{-}\right)_{2} \rightarrow \mathrm{A}^{-}+\mathrm{R}_{2}^{\prime} \mathrm{NCH}_{2} \mathrm{CHN}^{+}\left(\mathrm{CH}_{2} \mathrm{CO}_{2}^{-}\right)_{2}
$$

where $\mathrm{R}^{\prime}$ and $\mathrm{A}$ have the meaning noted in Reaction 3.12, and $\mathrm{A}^{-}=\mathrm{NO}^{-}, \mathrm{NO}_{2}^{-}$, and $\mathrm{OH}^{-}$.

\subsubsection{Propagation Reactions for EDTA to NTA and IDA}

\section{Through Free Radical Formed in Reaction 3.12}

The propagation reactions for the radical from EDTA are closely related to the reactions described for the reactions of the radical derived from HEDTA.

$$
\begin{aligned}
& \mathrm{R}_{2}^{\prime} \mathrm{NCH}_{2} \mathrm{CHN}\left(\mathrm{CH}_{2} \mathrm{CO}_{2}^{-}\right)_{2}+\mathrm{NO} \rightarrow \mathrm{R}_{2}^{\prime} \mathrm{NCH}_{2} \mathrm{CH}(\mathrm{NO}) \mathrm{N}\left(\mathrm{CH}_{2} \mathrm{CO}_{2}^{-}\right)_{2} \\
& \mathrm{R}_{2}^{\prime} \mathrm{NCH}_{2} \mathrm{CHN}\left(\mathrm{CH}_{2} \mathrm{CO}_{2}^{-}\right)_{2}+\mathrm{NO}_{2} \rightarrow \mathrm{R}_{2}^{\prime} \mathrm{NCH}_{2} \mathrm{CH}\left(\mathrm{NO}_{2}\right) \mathrm{N}_{(}\left(\mathrm{CH}_{2} \mathrm{CO}_{2}^{-}\right)_{2} \\
& \mathrm{R}_{2}^{\prime} \mathrm{NCH}_{2} \mathrm{CHN}\left(\mathrm{CH}_{2} \mathrm{CO}_{2}^{-}\right)_{2}+\mathrm{NO}_{2} \rightarrow \mathrm{R}_{2}^{\prime} \mathrm{NCH}_{2} \mathrm{CH}(\mathrm{ONO}) \mathrm{N}\left(\mathrm{CH}_{2} \mathrm{CO}_{2}^{-}\right)_{2}
\end{aligned}
$$




$$
\begin{aligned}
& \mathrm{R}_{2}^{\prime} \mathrm{NCH}_{2} \mathrm{CHN}\left(\mathrm{CH}_{2} \mathrm{CO}_{2}^{-}\right)_{2}+\mathrm{OH} \rightarrow \mathrm{R}_{2}^{\prime} \mathrm{NCH}_{2} \mathrm{CH}(\mathrm{OH}) \mathrm{N}\left(\mathrm{CH}_{2} \mathrm{CO}_{2}^{-}\right)_{2} \\
& \mathrm{R}_{2}^{\prime} \mathrm{NCH}_{2} \mathrm{CHN}\left(\mathrm{CH}_{2} \mathrm{CO}_{2}^{-}\right)_{2}+\mathrm{NO}_{2}^{-} \rightarrow \mathrm{R}_{2}^{\prime} \mathrm{NCH}_{2} \mathrm{CH}\left(\mathrm{NO}_{2}^{-}\right) \mathrm{N}_{2}\left(\mathrm{CH}_{2} \mathrm{CO}_{2}^{-}\right)_{2} \\
& \mathrm{~A}+\mathrm{R}_{2}^{\prime} \mathrm{NCH}_{2} \mathrm{CH}\left(\mathrm{NO}_{2}^{-}\right) \mathrm{N}\left(\mathrm{CH}_{2} \mathrm{CO}_{2}^{-}\right)_{2} \rightarrow \mathrm{A}^{-}+\mathrm{R}_{2}^{\prime} \mathrm{NCH}_{2} \mathrm{CH}\left(\mathrm{NO}_{2}\right) \mathrm{N}\left(\mathrm{CH}_{2} \mathrm{CO}_{2}^{-}\right)_{2}
\end{aligned}
$$

The reaction products in this sequence also have two electronegative atoms bonded to the carbon atom from which the hydrogen atom was removed. As discussed in Sections 3.2 and 3.4, hydrolysis provides an aldehyde fragment and IDA, and the aldehyde fragment is readily oxidized to NTA. These compounds may also be converted into amides and then hydrolyzed in the alkaline waste to produce IDA and NTA.

\section{Through the Electron Transfer Intermediate Formed in Reaction 3.13}

Propagation reactions for the degradation of EDTA can proceed via the electron transfer intermediate described in Reaction 3.13:

$$
\begin{aligned}
& \mathrm{R}_{2}^{\prime} \mathrm{NCH}_{2} \mathrm{CH}_{2} \mathrm{~N}^{+}\left(\mathrm{CH}_{2} \mathrm{CO}_{2}^{-}\right)_{2} \rightarrow \mathrm{R}_{2}^{\prime} \mathrm{NCH}_{2} \mathrm{CH}_{2} \mathrm{~N}^{+}=\mathrm{CH}_{2}\left(\mathrm{CH}_{2} \mathrm{CO}_{2}^{-}\right)+\mathrm{CO}_{2}^{-} \\
& \mathrm{R}_{2}^{\prime} \mathrm{NCH}_{2} \mathrm{CH}_{2} \mathrm{~N}^{+}=\mathrm{CH}_{2}\left(\mathrm{CH}_{2} \mathrm{CO}_{2}^{-}\right)+\mathrm{OH}^{-} \rightarrow \mathrm{R}_{2}^{\prime} \mathrm{NCH}_{2} \mathrm{CH}_{2} \mathrm{NH}\left(\mathrm{CH}_{2} \mathrm{CO}_{2}^{-}\right)+\mathrm{CH}_{2} \mathrm{O}
\end{aligned}
$$

The hydrogen atom and cation radical pathways differ in this instance. The abstraction reaction leads to NTA and IDA. In contrast, the electron transfer pathway leads to ED3A, carbon dioxide, and formaldehyde.

Similar reactions may be initiated by radicals that are thermally produced by the decomposition of inorganic constituents of the wastes. But the thermally initiated radical reactions are not particularly important for the Hanford waste because such reactions have high activation energies and proceed very slowly at typical tank waste storage temperatures.

\subsection{Base-Catalyzed Ionic Oxidation Reactions}

Hydroxide ion-initiated transformations of aldehydes are an important source of hydrogen in Hanford wastes, additionally yielding sodium carboxylates. Ashby and associates (1992, 1993, 1994) have described the importance of this variant of the Cannizzaro reaction (Lowry and Richardson 1987; Carey and Sundberg 1990; March 1992) in simulated wastes for the production of hydrogen and sodium formate from formaldehyde:

$$
\begin{aligned}
& \mathrm{H}_{2} \mathrm{CO}+\mathrm{OH}^{-} \rightarrow \mathrm{H}_{2} \mathrm{COH}\left(\mathrm{O}^{-}\right) \\
& \mathrm{H}_{2} \mathrm{COH}\left(\mathrm{O}^{-}\right)+\mathrm{OH}^{-} \rightarrow \mathrm{H}_{2} \mathrm{C}\left(\mathrm{O}^{-}\right)_{2}+\mathrm{H}_{2} \mathrm{O} \\
& \mathrm{H}_{2} \mathrm{C}\left(\mathrm{O}^{-}\right)_{2}+\mathrm{H}_{2} \mathrm{O} \rightarrow \mathrm{HCO}_{2}^{-}+\mathrm{OH}^{-}+\mathrm{H}_{2}
\end{aligned}
$$

As outlined in Section 3.1, formaldehyde is believed to be an important product of chelator fragmentation, and it is especially susceptible to the reaction sequence in Reactions 3.22 to 3.24 . 


\subsection{Ionic Oxidation Reactions Induced by the Nitrite-Aluminate Complex}

The simultaneous coupling of a hydroxyl group of the organic complexant and nitrite ion on an aluminate ion can provide a very convenient pathway for the transfer of hydrogen from the organic molecule to the nitrite ion. This reaction, which was postulated by Stock (1992) and Barefield and his coworkers $(1995,1996)$, finds strong precedent in classical organic reactions including the Oppenhauer oxidation (Lowry and Richardson 1987; Carey and Sundberg 1990; March 1992) and the Tischenko reaction (Jencks 1969; March 1992). These processes proceed through cyclic transition states in which the hydrogen is transferred intramolecularly between two coordinated ligands. This chemistry is shown in Reactions 3.25 and 3.26, where $\mathrm{R}^{\prime \prime}$ is $\left(\mathrm{O}_{2} \mathrm{CCH}_{2}\right)_{2} \mathrm{NCH}_{2} \mathrm{CH}_{2}$ :

$$
\begin{aligned}
& \mathrm{R}^{\prime \prime} \mathrm{N}\left(\mathrm{CH}_{2} \mathrm{CO}_{2}^{-}\right) \mathrm{CH}_{2} \mathrm{CH}_{2} \mathrm{OH}+\mathrm{Al}(\mathrm{OH})_{4}^{-}+\mathrm{NO}_{2}^{-} \rightarrow \\
& \mathrm{R}^{\prime \prime} \mathrm{N}\left(\mathrm{CH}_{2} \mathrm{CO}_{2}^{-}\right) \mathrm{CH}_{2} \mathrm{CH}_{2} \mathrm{OAl}(\mathrm{OH})_{2} \mathrm{ON}=\mathrm{O}+\mathrm{OH}^{-} \\
& \mathrm{R}^{\prime \prime} \mathrm{N}\left(\mathrm{CH}_{2} \mathrm{CO}_{2}^{-}\right) \mathrm{CH}_{2} \mathrm{CH}_{2} \mathrm{OAl}^{-}(\mathrm{OH})_{2} \mathrm{ONH}=\mathrm{O} \rightarrow \\
& \mathrm{R}^{\prime \prime} \mathrm{N}\left(\mathrm{CH}_{2} \mathrm{CO}_{2}^{-}\right) \mathrm{CH}_{2} \mathrm{CHO}+\mathrm{Al}(\mathrm{OH})_{2} \mathrm{O}^{-}+\mathrm{HNO}
\end{aligned}
$$

This reaction sequence provides a pathway for the transformation of a hydroxyl group in a complexant or its oxidation products into a carbonyl group. The occurrence of this reaction may be responsible for the rapid disappearance of glycolate ion from the waste (Barefield et al. 1995, 1996). The reaction also may be responsible for the oxidation of other intermediate alcohols formed in the initial free radical reactions of HEDTA and EDTA such as the products of Reactions 3.7 and 3.17.

\subsection{Hydrolysis Reactions}

Many molecules formed as a consequence of radical-radical or radical-anion propagation reactions have two electronegative substituents bonded to a tetrahedral carbon atom and are therefore readily hydrolyzed in the aqueous phase of the waste (Jencks 1969; Lowry and Richardson 1987; Carey and Sundberg 1990; March 1992). Other molecules are esters of inorganic acids that are also readily destroyed by hydrolysis (Jencks 1969). Some are nitroso compounds that rapidly rearrange into oximes, substances that are susceptible to hydrolysis (Jencks 1969; Lowry and Richardson 1987; Carey and Sundberg 1990; March 1992). Others contain activated methylene groups that spontaneously are hydrolyzed. Virtually every product of the reaction sequences outlined in Section 3.1 is eventually converted into a new carbonyl compound of lower energy content than the original complexant by one or more of these reaction pathways.

\section{Inorganic Esters}

The products of O-nitration formed by the reactions of nitrogen dioxide with the radicals in Reactions 3.5 and 3.16 are very rapidly hydrolyzed to hydroxy derivatives in basic solution (Jencks 1969; March 1992). 


$$
\begin{aligned}
& \mathrm{RN}\left(\mathrm{CH}_{2} \mathrm{CO}_{2}^{-}\right) \mathrm{CH}(\mathrm{ONO}) \mathrm{CH}_{2} \mathrm{OH}+\mathrm{H}_{2} \mathrm{O} \rightarrow \mathrm{RN}\left(\mathrm{CH}_{2} \mathrm{CO}_{2}^{-}\right) \mathrm{CH}(\mathrm{OH}) \mathrm{CH}_{2} \mathrm{OH}+\mathrm{HNO}_{2} \\
& \mathrm{R}_{2}^{\prime} \mathrm{NCH}_{2} \mathrm{CH}(\mathrm{ONO}) \mathrm{N}\left(\mathrm{CH}_{2} \mathrm{CO}_{2}^{-}\right)_{2}+\mathrm{H}_{2} \mathrm{O} \rightarrow \mathrm{R}_{2}^{\prime} \mathrm{NCH}_{2} \mathrm{CH}(\mathrm{OH}) \mathrm{N}\left(\mathrm{CH}_{2} \mathrm{CO}_{2}^{-}\right)_{2}+\mathrm{HNO}_{2}
\end{aligned}
$$

\section{Molecules with Two Electronegative Substituents on One Carbon Atom}

The products formed in the reaction just discussed are identical to the products formed through the reactions of the free radical intermediates with hydroxyl radical in Reactions 3.7 and 3.17 , respectively. These substance have two electronegative atoms bonded to carbon and can be hydrolyzed, although slowly in alkaline solution, as illustrated in Reactions 3.29 and 3.30:

$$
\begin{aligned}
& \mathrm{RN}\left(\mathrm{CH}_{2} \mathrm{CO}_{2}^{-}\right) \mathrm{CH}(\mathrm{OH}) \mathrm{CH}_{2} \mathrm{OH}+\mathrm{H}_{2} \mathrm{O} \rightarrow \mathrm{RNH}\left(\mathrm{CH}_{2} \mathrm{CO}_{2}^{-}\right)+\mathrm{OCHCH}_{2} \mathrm{OH} \\
& \mathrm{R}_{2}^{\prime} \mathrm{NCH}_{2} \mathrm{CH}(\mathrm{OH}) \mathrm{N}\left(\mathrm{CH}_{2} \mathrm{CO}_{2}^{-}\right)_{2}+\mathrm{H}_{2} \mathrm{O} \rightarrow \mathrm{R}_{2}^{\prime} \mathrm{NCH}_{2} \mathrm{CHO}+\mathrm{HN}\left(\mathrm{CH}_{2} \mathrm{CO}_{2}^{-}\right)_{2}
\end{aligned}
$$

The products of Reaction 3.29 are ED3A and a hydroxy aldehyde that is readily converted into glycolate or oxalate ion. The products of Reaction 3.30 are IDA and another reactive aldehyde that is readily converted into NTA.

\section{Nitroso Compounds}

Organic nitroso compounds are formed in the reactions between the original carbon radicals and nitric oxide in solution as illustrated in Reactions 3.4 and 3.14. The nitroso compounds rearrange to oximes which hydrolyze providing a carbonyl compound often an amide in the case of the compounds in the waste and hydroxylamine (Jencks 1969; Lowry and Richardson 1987; Carey and Sundberg 1990, March 1992). The conversion of the nitroso compound from Reaction 3.4 into the corresponding amide and hydroxylamine is shown in Reactions 3.31 and 3.32 .

$$
\begin{aligned}
& \mathrm{RN}\left(\mathrm{CH}_{2} \mathrm{CO}_{2}^{-}\right) \mathrm{CH}(\mathrm{NO}) \mathrm{CH}_{2} \mathrm{OH} \rightarrow \mathrm{RN}\left(\mathrm{CH}_{2} \mathrm{CO}_{2}^{-}\right) \mathrm{C}(\mathrm{NOH}) \mathrm{CH}_{2} \mathrm{OH} \\
& \mathrm{RN}\left(\mathrm{CH}_{2} \mathrm{CO}_{2}^{-}\right) \mathrm{C}(\mathrm{NOH}) \mathrm{CH}_{2} \mathrm{OH}+\mathrm{H}_{2} \mathrm{O} \rightarrow \mathrm{RN}\left(\mathrm{CH}_{2} \mathrm{CO}_{2}^{-}\right) \mathrm{COCH}_{2} \mathrm{OH}+\mathrm{NH}_{2} \mathrm{OH}
\end{aligned}
$$

Inasmuch as nitric oxide is ubiquitous in the wastes, this reaction pathway has long been postulated as an important reaction pathway (Meisel et al. 1991a, 1991b, 1992, 1993).

\section{Nitro Compounds}

The nitro compounds formed in Reactions 3.6. 3.9, 3.15 and 3.19 also contain two electronegative atoms bonded to a tetrahedral carbon atom and are therefore susceptible to the same decomposition reactions as the other substances of this class. However, the nitro compounds also contain acidic hydrogen atoms which can be abstracted by the hydroxide ions in the waste (Lowry and Richardson 1987; Carey and Sundberg 1990; March 1992). These substances therefore have several different channels for their reactions. The chemical reactions with base are certain to be very rapid and probably occur prior to the other possible hydrolysis reactions to produce the anionic intermediate, as shown in Reactions 3.33 and 3.34. 


$$
\begin{aligned}
& \mathrm{RN}\left(\mathrm{CH}_{2} \mathrm{CO}_{2}^{-}\right) \mathrm{CH}\left(\mathrm{NO}_{2}\right) \mathrm{CH}_{2} \mathrm{OH}+\mathrm{OH}^{-} \rightarrow \mathrm{RN}\left(\mathrm{CH}_{2} \mathrm{CO}_{2}^{-}\right) \mathrm{C}^{-}\left(\mathrm{NO}_{2}\right) \mathrm{CH}_{2} \mathrm{OH}+\mathrm{H}_{2} \mathrm{O} \\
& \mathrm{R}_{2}^{\prime} \mathrm{NCH}_{2} \mathrm{CH}\left(\mathrm{NO}_{2}\right) \mathrm{N}_{2}\left(\mathrm{CH}_{2} \mathrm{CO}_{2}^{-}\right)_{2}+\mathrm{OH}^{-} \rightarrow \mathrm{R}_{2}^{\prime} \mathrm{NCH}_{2} \mathrm{CH}^{-}\left(\mathrm{NO}_{2}\right) \mathrm{N}^{2}\left(\mathrm{CH}_{2} \mathrm{CO}_{2}^{-}\right)_{2}+\mathrm{H}_{2} \mathrm{O}
\end{aligned}
$$

Recent investigations of the chemistry of nitrogen dioxide and nitric oxide have demonstrated that the salt of nitromethane reacts with nitric oxide and nitrogen dioxide to form even more oxidized products with two nitro groups or one nitro and one nitroso group bonded to the single carbon atom (Reszka et al. 1996). This recent work suggests that the nitro compounds formed in Hanford waste may react similarly because of the significant concentrations of the two potentially reactive gases to produce substances with two nitro groups or one nitro group and one nitroso group bonded to the carbon atom. The chemistry is illustrated in Reactions 3.35 and 3.36 for the product of Reaction 3.34.

$$
\begin{aligned}
& \mathrm{R}_{2}^{\prime} \mathrm{NCH}_{2} \mathrm{C}^{-}\left(\mathrm{NO}_{2}\right) \mathrm{N}\left(\mathrm{CH}_{2} \mathrm{CO}_{2}^{-}\right)_{2}+\mathrm{NO}_{2} \rightarrow \mathrm{R}_{2}^{\prime} \mathrm{NCH}_{2} \mathrm{C}_{2}\left(\mathrm{NO}_{2}^{-}\right)\left(\mathrm{NO}_{2}\right) \mathrm{N}\left(\mathrm{CH}_{2} \mathrm{CO}_{2}^{-}\right)_{2} \\
& \mathrm{R}_{2}^{\prime} \mathrm{NCH}_{2} \mathrm{C}^{-}\left(\mathrm{NO}_{2}\right) \mathrm{N}\left(\mathrm{CH}_{2} \mathrm{CO}_{2}^{-}\right)_{2}+\mathrm{NO} \rightarrow \mathrm{R}_{2}^{\prime} \mathrm{NCH}_{2} \mathrm{C}\left(\mathrm{NO}_{2}^{-}\right)(\mathrm{NO}) \mathrm{N}\left(\mathrm{CH}_{2} \mathrm{CO}_{2}^{-}\right)_{2}
\end{aligned}
$$

The chemistry of substances produced in these reactions has not specifically been investigated. But it is evident that the products, which are anion radicals, would have a rich chemistry in the aqueous alkaline waste solutions. For example, the decomposition of the anion radical formed in Reaction 3.36 by the loss of nitrite ion would provide a nitroso derivative related to the oxime discussed in the previous section. Simple electron transfer converts the products of Reactions 3.35 and 3.36 into molecules with three electronegative atoms bonded to the same reactive carbon atom. Such compounds should have relatively short lifetimes in the waste since the reactive carbon atom in these substances is in the oxidation state of a carboxylate. Hydrolysis would eventually produce NTA and IDA, as given in Reaction 3.37:

$$
\begin{aligned}
& \mathrm{R}_{2}^{\prime} \mathrm{NCH}_{2} \mathrm{C}\left(\mathrm{NO}_{2}\right)_{2} \mathrm{~N}\left(\mathrm{CH}_{2} \mathrm{CO}_{2}^{-}\right)_{2}+3 \mathrm{OH}^{-} \rightarrow \\
& \quad \mathrm{R}_{2}^{\prime} \mathrm{NCH}_{2} \mathrm{CO}_{2}^{-}+\mathrm{HN}\left(\mathrm{CH}_{2} \mathrm{CO}_{2}^{-}\right)_{2}+2 \mathrm{NO}_{2}^{-}+\mathrm{H}_{2} \mathrm{O}
\end{aligned}
$$

\section{N-Methylene Derivatives}

$\mathrm{N}$-methylene derivatives are formed in the fragmentation reactions of the initial electron transfer reaction products shown in Reactions 3.10 and 3.20. These compounds are well known to undergo hydrolysis to liberate the amine and formaldehyde (Lowry and Richardson 1987; Carey and Sundberg 1990; March 1992).

$$
\mathrm{R}_{2}^{\prime} \mathrm{NCH}_{2} \mathrm{CH}_{2} \mathrm{~N}^{+}=\mathrm{CH}_{2}\left(\mathrm{CH}_{2} \mathrm{CO}_{2}^{-}\right)+\mathrm{OH}^{-} \rightarrow \mathrm{R}_{2}^{\prime} \mathrm{NCH}_{2} \mathrm{CH}_{2} \mathrm{NH}\left(\mathrm{CH}_{2} \mathrm{CO}_{2}{ }^{-}\right)+\mathrm{CH}_{2} \mathrm{O}
$$

The reactions outlined in this section illustrate the general aspects of the chemistry exhibited by the waste molecules and their oxidation products. The inorganic reaction products are discussed in Section 4. 


\subsection{The Reduction Pathway to Gaseous Products}

The principal gaseous products of reactions between the complexants and the inorganic constituents in Hanford wastes are hydrogen, nitrous oxide, ammonia, and nitrogen. These substances have been observed in many laboratory studies with simulants and in laboratory studies with actual waste samples (Ashby et al. 1992, 1993, 1994; Barefield et al. 1995, 1996; Bryan and Pederson 1993, 1994, 1996; Camaioni et al. 1997; Delegard 1980; Johnson et al. 1997; King et al. 1997; Meisel et al. 1991a, 1991b, 1992,1993; Person 1996). These same products are found in the dome space of actual waste tanks and in gas samples obtained using the Retained Gas Sampler (Johnson et al. 1997; Shekarriz et al. 1997). All but ammonia and nitrous oxide are sparingly soluble in the concentrated, caustic wastes and escape further reaction.

Below the surface of the waste, in the absence of oxygen (air), the most abundant reaction products are ammonia, nitrous oxide, and nitrogen. The reduction of nitrite ion to these compounds appears to be the dominant reductive reaction pathway, coupled with the oxidation of the organic complexants and their degradation products. From a chemical viewpoint, hydrogen is a relatively minor byproduct of the oxidation-reduction reactions of organic complexants with nitrite ion. This feature has been demonstrated in several ways. Most important, the retained gas sampler (RGS) measurements of several different wastes show that the mole ratio of hydrogen/ (nitrogen + nitrous oxide + ammonia) is generally less than one (Shekarriz et al. 1997). Laboratory work also points to the greater abundance of the nitrogenous gases. Hydroxylamine, one of the important intermediates responsible for gas formation, decomposes rapidly to produce nitrogen and ammonia but provides no hydrogen (Barefield et al. 1995, 1996). The ratio of hydrogen/ (nitrogen + nitrous oxide + ammonia) for the decomposition of representative complexants is low (Ashby et al. 1994; Barefield et al. 1995, 1996; Camaioni et al. 1997).

The stiochiometry of the reactions provides insight concerning this feature of the chemistry. A balanced equation for the conversion of a hydroxyethyl fragment into an amine, carbon dioxide, and hydrogen is given in Reaction 4.1, where $R^{\prime}$ is used to represent the other groups bonded to the nitrogen atom:

$$
\mathrm{R}_{2}^{\prime} \mathrm{NCH}_{2} \mathrm{CH}_{2} \mathrm{OH}+3 \mathrm{H}_{2} \mathrm{O} \rightarrow \mathrm{R}_{2}^{\prime} \mathrm{NH}+2 \mathrm{CO}_{2}+5 \mathrm{H}_{2}
$$

In principle, five moles of hydrogen could form for each fully oxidized hydroxyethyl fragment. Equivalent conversion reactions can be written with nitrite ion to yield the three reduced nitrogenous gases with the organic hydrogen converted to water rather than to dihydrogen, as follows:

$$
\begin{aligned}
& 6 \mathrm{R}_{2}^{\prime} \mathrm{NCH}_{2} \mathrm{CH}_{2} \mathrm{OH}+10 \mathrm{HNO}_{2}+\mathrm{H}_{2} \mathrm{O} \rightarrow 6 \mathrm{R}_{2}^{\prime} \mathrm{NH}+12 \mathrm{CO}_{2}+2 \mathrm{H}_{2} \mathrm{O}+10 \mathrm{NH}_{3} \\
& 4 \mathrm{R}_{2}^{\prime} \mathrm{NCH}_{2} \mathrm{CH}_{2} \mathrm{OH}+20 \mathrm{HNO}_{2} \rightarrow 4 \mathrm{R}_{2}^{\prime} \mathrm{NH}+8 \mathrm{CO}_{2}+18 \mathrm{H}_{2} \mathrm{O}+10 \mathrm{~N}_{2} \mathrm{O} \\
& 6 \mathrm{R}_{2}^{\prime} \mathrm{NCH}_{2} \mathrm{CH}_{2} \mathrm{OH}+20 \mathrm{HNO}_{2} \rightarrow 6 \mathrm{R}_{2}^{\prime} \mathrm{NH}+12 \mathrm{CO}_{2}+22 \mathrm{H}_{2} \mathrm{O}+10 \mathrm{~N}_{2}
\end{aligned}
$$

Equivalent results are obtained for the reaction under alkaline conditions: 


$$
6 \mathrm{R}_{2}^{\prime} \mathrm{NCH}_{2} \mathrm{CH}_{2} \mathrm{OH}+20 \mathrm{NaNO}_{2}+4 \mathrm{NaOH} \rightarrow 6 \mathrm{R}_{2}^{\prime} \mathrm{NH}+12 \mathrm{Na}_{2} \mathrm{CO}_{3}+14 \mathrm{H}_{2} \mathrm{O}+10 \mathrm{~N}_{2}
$$

The oxidation of one hydroxyethyl fragment produces 5 hydrogen, 10/6 ammonia, 10/4 nitrous oxide, or 10/6 nitrogen molecules. Inasmuch as the hydrogen/(nitrogen + nitrous oxide + ammonia) mole ratio is small for the reactions of the waste components, it is evident the chemistry for the oxidation of the complexants is dominated by the conversion of nitrite ion into lower valent nitrogen compounds. This finding is in accord with the suggestion that formaldehyde is the most prominent source of hydrogen through the reaction pathway discussed in Section 3.2 .

Both thermal and radiolytic pathways lead to the formation of ammonia and other nitrogen-containing gases. Although the explicit origins of ammonia have not been defined by experiments with $\mathrm{N}-15$, the majority of the nitrogen in ammonia, nitrous oxide, and nitrogen appears to form from inorganic sources rather than from organic nitrogen in the complexants (Ashby et al. 1993, 1994; Meisel et al. 1993). Using N-15-labeled nitrite ion, Meisel et al. (1993) obtained about $85 \% \mathrm{~N}-15$ labeled gases. The observations establish that inorganic nitrogen is by far the most important source of nitrogen and nitrous oxide. However, it is evident that ammonia is formed from both the complexants and from the inorganic constituents. These two reaction pathways for ammonia formation are discussed in Sections 4.1 and 4.2.

\subsection{Ammonia from Organic Sources}

Hanford tank wastes originally contained very large quantities of both EDTA and HEDTA (Webb et al. 1995). Investigations at PNNL (Campbell et al. 1993, 1994, 1995, 1996) have shown that these two nitrogen-containing complexants have been substantially converted into other nitrogen-containing compounds, including the anions of ED3A, NTA and IDA; or oxalate, formate, and carbonate ions during the years of storage. The chemical reaction pathways for formation of these compounds and other intermediate oxidation products are outlined in Figure 3.1 for the oxidative decomposition of EDTA, and other representative chemical pathways for the degradation of HEDTA were described in Section 3. These considerations indicate that these molecules are systematically oxidized and fragmented until the tertiary nitrogen atom in the original complexant is converted into a primary nitrogen atom in an intermediate such as uEDTA or glycine. The nitrogen atoms in the substances with primary amino groups can be rather directly converted into ammonia by additional oxidative reactions that produce an amide or a nitrile.

\subsubsection{Ammonia from Amides}

One pathway for ammonia production form the complexant is through a primary amide. The complex reactions in which the original methylene groups of HEDTA and EDTA are converted by oxidation and hydrolysis into carbonyl groups provide a simple method for carbonnitrogen bond cleavage and the conversion of the original tertiary nitrogen atom into a primary or secondary amide. Base-catalyzed hydrolysis reactions of the several different amides liberate primary and secondary amines. These molecules experience the same reactions and eventually 
provide ammonia. These processes are illustrated in the following equations for HEDTA and ED3A where again $\mathrm{R}^{\prime}={ }^{-} \mathrm{O}_{2} \mathrm{CCH}_{2}$ :

$$
\begin{aligned}
\mathrm{R}_{2}^{\prime} \mathrm{NCH}_{2} \mathrm{CH}_{2} \mathrm{~N}\left(\mathrm{CH}_{2} \mathrm{CO}_{2}^{-}\right) \mathrm{CH}_{2} \mathrm{CH}_{2} \mathrm{OH}(\mathrm{HEDTA}) \\
\rightarrow \rightarrow \mathrm{R}_{2}^{\prime} \mathrm{NCH}_{2} \mathrm{CON}_{2}\left(\mathrm{CH}_{2} \mathrm{CO}_{2}^{-}\right) \mathrm{CH}_{2} \mathrm{CH}_{2} \mathrm{OH} \\
\rightarrow \mathrm{R}_{2}^{\prime} \mathrm{NCH}_{2} \mathrm{CH}_{2} \mathrm{~N}\left(\mathrm{COCO}_{2}^{-}\right) \mathrm{CH}_{2} \mathrm{CH}_{2} \mathrm{OH} \\
\rightarrow \mathrm{R}_{2}^{\prime} \mathrm{NCH}_{2} \mathrm{CH}_{2} \mathrm{~N}\left(\mathrm{CH}_{2} \mathrm{CO}_{2}^{-}\right) \mathrm{COCH}_{2} \mathrm{OH}
\end{aligned}
$$

$$
\begin{aligned}
\mathrm{R}_{2}^{\prime} \mathrm{NCH}_{2} \mathrm{CH}_{2} \mathrm{NH}\left(\mathrm{CH}_{2} \mathrm{CO}_{2}^{-}\right)(\mathrm{ED} 3 \mathrm{~A}) \\
\rightarrow \mathrm{R}_{2}^{\prime} \mathrm{NCH}_{2} \mathrm{CH}_{2} \mathrm{NH}\left(\mathrm{COCO}_{2}^{-}\right) \\
\rightarrow \mathrm{R}_{2}^{\prime} \mathrm{NCH}_{2} \mathrm{CONH}\left(\mathrm{CH}_{2} \mathrm{CO}_{2}^{-}\right)
\end{aligned}
$$

The hydrolysis reactions of these compounds provide primary or secondary amines. The primary amines that are produced in these sequences may oxidize to produce amides that subsequently yield ammonia. For example, the oxidation-hydrolysis sequence starting with Reaction 4.9 eventually converts ED3A into an amine that has been identified in the waste, unsymmetric ethylenediaminediacetate anion. This compound can be oxidized to the corresponding amide and hydrolyzed to give NTA and ammonia:

$$
\begin{aligned}
& \mathrm{R}_{2}^{\prime} \mathrm{NCH}_{2} \mathrm{CH}_{2} \mathrm{NHCOCO}_{2}^{-} \rightarrow \mathrm{R}_{2}^{\prime} \mathrm{NCH}_{2} \mathrm{CH}_{2} \mathrm{NH}_{2}+\mathrm{O}_{2} \mathrm{CCO}_{2}^{-} \\
& \mathrm{R}_{2}^{\prime} \mathrm{NCH}_{2} \mathrm{CH}_{2} \mathrm{NH}_{2} \rightarrow \mathrm{R}_{2}^{\prime} \mathrm{NCH}_{2} \mathrm{CONH}_{2} \rightarrow \mathrm{NTA}+\mathrm{NH}_{3}
\end{aligned}
$$

Glycine, an intermediate in several sequential decomposition reactions of EDTA and HEDTA (Figure 3.1), is converted into ammonia and oxalate ion:

$$
\mathrm{H}_{2} \mathrm{NCH}_{2} \mathrm{CO}_{2}^{-} \rightarrow \mathrm{H}_{2} \mathrm{NCOCO}_{2}^{-} \rightarrow \mathrm{O}_{2} \mathrm{CCO}_{2}^{-}+\mathrm{NH}_{3}
$$

Although glycine can be envisioned as a product of many reactions, it does not accumulate in the waste (Campbell et al. 1995, 1996). However, the compound, which is known to be destroyed about five times more rapidly than the formate ion during radiolysis (Camaioni et al. 1997), has been detected in laboratory studies of the long-term decomposition of HEDTA in simulated wastes (Barefield et al. 1995, 1996).

The low concentrations of ammonia in the waste coupled with the high activation energy for the reaction of ammonia with the carboxylate ion prevents the reconstitution of the amides. This chemistry and the constant evolution of ammonia from the waste drive these reactions.

\subsubsection{Ammonia from Nitriles}

There is evidence that some oximes or primary amides discussed in the preceding sections are converted into nitriles by dehydration reactions in the alkaline wastes. Barefield et al. $(1995,1996)$ found small concentrations of nitriles in long-term studies of decomposition pathways of HEDTA in simulated wastes. Simple aliphatic nitriles with more than four carbon 
atoms have been detected in the dome space of several Hanford tanks (Huckaby et al. 1995). Although these substances are apparently derived from normal paraffinic hydrocarbons, their existence in the waste provides an excellent precedent for the formation of other nitriles from the nonvolatile complexants.

The path to ammonia through the nitrile is illustrated by the oxidation and dehydration of $\mathrm{u}-\mathrm{ED} 2 \mathrm{~A}$ in Reaction 4.14 and the subsequent hydrolysis of the nitrile in Reaction 4.15:

$$
\begin{aligned}
& \mathrm{R}_{2}^{\prime} \mathrm{NCH}_{2} \mathrm{CH}_{2} \mathrm{NH}_{2} \rightarrow \mathrm{R}_{2}^{\prime} \mathrm{NCH}_{2} \mathrm{CONH}_{2} \rightarrow \mathrm{R}_{2}^{\prime} \mathrm{NCH}_{2} \mathrm{C} \equiv \mathrm{N} \\
& \mathrm{R}_{2}^{\prime} \mathrm{NCH}_{2} \mathrm{C} \equiv \mathrm{N}+\mathrm{OH}^{-}+\mathrm{H}_{2} \mathrm{O} \rightarrow \mathrm{R}_{2}^{\prime} \mathrm{NCH}_{2} \mathrm{CO}_{2}^{-}+\mathrm{NH}_{3}
\end{aligned}
$$

The oxidation, dehydration, and hydrolysis reactions of the nitroso compounds, nitriles, and amides are closely related processes. Many of the similar intermediates are involved in the reactions of this family of compounds. Specifically, an aldoxime can be dehydrated to produce the nitrile, and the initial product of hydrolysis of the nitrile is the corresponding amide.

In summary, ammonia is produced from tertiary amines such as EDTA and HEDTA by oxidation-hydrolysis sequences that eventually provide an intermediate with a primary amino group. Repetition of the reaction sequence gives a primary amide. Such compounds either hydrolyze directly to produce ammonia or are converted to a nitrile that subsequently hydrolyzes by a similar reaction pathway to form ammonia.

\subsection{Ammonia from Inorganic Sources}

The nitrite anion is the kinetically active oxidant in the Hanford waste tanks, and the nitrogen in ammonia also is formed from nitrite ion. Several lines of evidence indicate that the organic components serve an important role as reducing agents in this chemistry. The reaction sequences that are responsible for the conversion of nitrite ion into reduced nitrogenous gases occur thermally and radiolytically. Both sets of reactions proceed through nitrogen dioxide and nitric oxide. The principal distinction between the thermal and radiolytic reaction pathways is the relatively high activation energy for the thermal reaction. Because the reaction pathways are so similar, they will not be discussed separately.

While there is relatively little information available on chemical pathways for the conversion of nitrite ion into the nitrogenous gases in homogeneous solution free of potential inorganic catalysts, the interconversion reactions of nitrogen-containing ligands coordinated to transition metals has received considerable attention (Assefa and Stanbury 1997; MacNeil et al. 1997). This information provides an additional guide for discussing the chemistry that sequentially converts nitrite ion through the many available oxidation states eventually leading to ammonia.

The nitrite ion has a particularly large impact on radiation chemistry of Hanford wastes. Certain primary radiolytic products, most notably the hydrated electron and hydrogen radical, 
react with nitrate and nitrite ions to generate $\mathrm{NO}_{x}$ radicals, mainly $\mathrm{NO}_{2}$ and $\mathrm{NO}$ (Meisel et al. 1991a, 1991b, 1992, 1993, 1997). Important reactions include the following:

$$
\begin{aligned}
& \mathrm{e}_{\mathrm{aq}}^{-}+\mathrm{NO}_{3}^{-} \rightarrow \mathrm{NO}_{3}{ }^{2-} \\
& \mathrm{H}+\mathrm{NO}_{2}^{-} \rightarrow \mathrm{NO}+\mathrm{OH}^{-} \\
& \mathrm{NO}_{3}^{-}+\mathrm{e}_{\mathrm{aq}}^{-} \rightarrow \mathrm{NO}_{2}+2 \mathrm{OH}^{-} \\
& \mathrm{NO}_{2}^{-}+\mathrm{OH} \rightarrow \mathrm{NO}_{2}+\mathrm{OH}^{-} \\
& \mathrm{NO}_{2}^{-}+\mathrm{H} \rightarrow \mathrm{NO}+\mathrm{OH}^{-} \\
& \mathrm{NO}_{2}+\mathrm{RH} \rightarrow \mathrm{R}+\mathrm{H}^{+}+\mathrm{NO}_{2}^{-} \\
& \mathrm{NO}+\mathrm{NO}_{2}^{-} \rightarrow \mathrm{NO}^{-}+\mathrm{NO}_{2}
\end{aligned}
$$

Rates of reaction are sufficiently high that essentially all the primary radicals from water radiolysis are converted to NOx radicals.

\subsubsection{Ammonia from Inorganic Sources with No Organic Compounds Present}

The formation of ammonia from the reduction of the nitrite ion with no organic compounds present to serve as a reducing agent does not appear to be important. Bryan and Pederson (1996) measured gas products from heated and irradiated simulated waste mixtures and found no detectable concentrations of ammonia had been formed. Small concentrations of nitrogen, nitrous oxide, dinitrogen dioxide, oxygen, and hydrogen were observed in these tests. Dried simulated waste solids produced gas concentrations at or below the detection limit at temperatures up to $150^{\circ} \mathrm{C}$. Moist simulated waste solids generated small amounts of nitrogen dioxide, nitrous oxide, and nitrogen at temperatures above $120^{\circ} \mathrm{C}$. Approximately $1 \mathrm{mmole} / \mathrm{kg}$ waste per day of both nitrogen dioxide and nitrous oxide were formed at $150^{\circ} \mathrm{C}$. Higher yields of these products were obtained when either the dried or moist simulated waste solids were heated and irradiated at a dose rate $1.7 \times 10^{6} \mathrm{R} / \mathrm{h}$. The observations indicate that organic compounds are required for the formation of significant quantities of nitrogen-containing gases.

Ammonia may be formed from other inorganic reactions, but these reactions are not expected to be important in Hanford tanks. For example, the Haber process is used on an industrial scale to produce ammonia from the reaction of hydrogen and nitrogen in the presence of a catalyst (Thomas and Thomas 1969; Bottomley and Burns 1979). The reaction

$$
\mathrm{N}_{2}+3 \mathrm{H}_{2} \rightarrow 2 \mathrm{NH}_{3}
$$

is exothermic and is thermodynamically favored by low temperatures and high pressures. However, because of kinetic considerations, industrial ammonia synthesis is performed typically in the temperature range of 400 to $550^{\circ} \mathrm{C}$ and 100 to 1000 atmospheres total pressure.

The use of catalysts in ammonia synthesis is essential. Industrial catalysts commonly consist of reduced oxides of iron promoted with metal oxides such as alumina, silica, or zirconia and alkali and alkaline earth metals. The rate-determining step in ammonia synthesis from nitrogen and hydrogen is the dissociative adsorption of nitrogen onto those catalyst surfaces. In 
the absence of an appropriate catalyst and at temperatures relevant to Hanford Site waste tanks, the expected rate of ammonia formation from the thermally driven reaction of nitrogen and hydrogen is infinitesimally small.

The synthesis of ammonia from its elements and the decomposition of ammonia by radiolytic processes have been studied extensively (Spinks and Woods 1990; Bryan and Pederson 1996). Ammonia can be produced from the gas-phase reaction of hydrogen and nitrogen in the presence of gamma radiation. Ammonia yields are usually quite low, with $\mathrm{G}\left(\mathrm{NH}_{3}\right)$ ranging from 0.7 to 1.5 molecules $/ 100 \mathrm{eV}$ (Spinks and Woods 1990). In comparison, the radiolytic yield for the decomposition of ammonia to nitrogen and hydrogen is -6.3 molecules $/ 100 \mathrm{eV}$ (Sorokin and Pshezhetskii 1964). The radiolytic formation of ammonia from nitrogen and hydrogen can be only a very minor source of ammonia compared with solution phase reactions involving the nitrite ion and organic waste components.

\subsubsection{Ammonia from Hydroxylamine}

Hydroxylamine appears to be a key intermediate in the generation of gases from Hanford wastes. Once formed, the compound relatively rapidly decomposes in catalyzed and uncatalyzed reactions to form nitrogen, ammonia, and nitrous oxide (Barefield et al. 1996). Hydrogen is not usually formed in the reactions of hydroxylamine (Barefield et al. 1996).

There are several ways to form hydroxylamine from the complexant and solvents in the wastes. The most direct and most obvious pathway involves the initial reaction of an organic radical with nitric oxide to form a nitroso compound. The underlying chemistry, which was discussed in Section 3, postulates that nitroso compound are produced as shown in Reaction 3.4:

$$
\mathrm{RN}\left(\mathrm{CH}_{2} \mathrm{CO}_{2}^{-}\right) \mathrm{CHCH}_{2} \mathrm{OH}+\mathrm{NO} \rightarrow \mathrm{RN}\left(\mathrm{CH}_{2} \mathrm{CO}_{2}{ }^{-}\right) \mathrm{CH}(\mathrm{NO}) \mathrm{CH}_{2} \mathrm{OH}
$$

These substances isomerize into an oxime and subsequently undergo hydrolysis to form a carbonyl compound and hydroxylamine:

$$
\begin{aligned}
& \mathrm{RN}\left(\mathrm{CH}_{2} \mathrm{CO}_{2}^{-}\right) \mathrm{CH}(\mathrm{NO}) \mathrm{CH}_{2} \mathrm{OH} \rightarrow \mathrm{RN}\left(\mathrm{CH}_{2} \mathrm{CO}_{2}^{-}\right) \mathrm{C}(\mathrm{NOH}) \mathrm{CH}_{2} \mathrm{OH} \\
& \mathrm{RN}\left(\mathrm{CH}_{2} \mathrm{CO}_{2}^{-}\right) \mathrm{C}(\mathrm{NOH}) \mathrm{CH}_{2} \mathrm{OH} \rightarrow \mathrm{RN}\left(\mathrm{CH}_{2} \mathrm{CO}_{2}^{-}\right) \mathrm{COCH}_{2} \mathrm{OH}+\mathrm{H}_{2} \mathrm{NOH}
\end{aligned}
$$

The nitrogen atom (bold) from the nitric oxide, which originated in nitrite ion, is converted into the reduced nitrogen atom in hydroxylamine. The organic hydrogen atom (bold) in the original complexant eventually appears as a hydroxylic hydrogen atom in hydroxylamine or in water. This oxidation reaction sequence circumvents the conversion of an organic hydrogen atom.into molecular hydrogen. As already discussed in Section 3, this oxidation-hydrolysis reaction sequence is one of the available routes for the conversion of HEDTA and EDTA into lower energy products.

Hydroxylamine is not stable in alkaline solution. When pure hydroxylamine is dissolved in pure water containing $1 \underline{\mathrm{M}}$ reagent grade sodium hydroxide, the compound is converted into 
ammonia and nitrogen with small amounts of nitrous oxide, but no hydrogen, in 30 hours (Barefield et al. 1996). Many cations accelerate the decomposition of this hydroxylamine (Van Der Puy 1985; Van Der Puy and Dimmit 1985).

The stoichiometry for the base-catalyzed decomposition of pure hydroxylamine to ammonia and nitrogen is given in the following equation (Barefield et al. 1996):

$$
3 \mathrm{NH}_{2} \mathrm{OH} \rightarrow \mathrm{NH}_{3}+\mathrm{N}_{2}+3 \mathrm{H}_{2} \mathrm{O}
$$

The pathway for the formation of these compounds has been studied at Georgia Institute of Technology. Barefield and his associates (1996) have tentatively proposed that the reactions of hydroxylamine in alkaline solution proceed via two rather novel intermediates, nitrene and nitrosyl anion, $\left(\mathrm{NO}^{-}\right)$, both of which are formed from hydroxylamine in the presence of hydroxide ion. The initial acid base equilibria are shown in Reactions 4.27 and 4.28, and nitrene formation is shown in Reaction 4.29.

$$
\begin{aligned}
& \mathrm{HONH}_{2}+\mathrm{OH}^{-} \rightarrow \mathrm{H}_{2} \mathrm{NO}^{-}+\mathrm{HOH} \\
& \mathrm{HONH}_{2}+\mathrm{OH}^{-} \rightarrow \mathrm{HONH}^{-}+\mathrm{HOH} \\
& \mathrm{HONH}^{-} \rightarrow \mathrm{NH}+\mathrm{OH}^{-}
\end{aligned}
$$

The nitrene generated in Reaction 4.29 abstracts a hydride ion from hydroxylamine anion to produce amide anion, which instantly protonates to form ammonia; and HNO, which, according to this formulation, reacts with the anion of hydroxylamine to produce an adduct that dehydrates to give nitrogen.

$$
\begin{aligned}
& \mathrm{NH}+\mathrm{H}_{2} \mathrm{NO}^{-} \rightarrow \mathrm{H}_{2} \mathrm{~N}^{-}+\mathrm{HNO} \\
& \mathrm{H}_{2} \mathrm{~N}^{-}+\mathrm{HOH} \rightarrow \mathrm{NH}_{3}+\mathrm{OH}^{-} \\
& \mathrm{H}_{2} \mathrm{NO}^{-}+\mathrm{NO}^{-} \rightarrow \mathrm{H}_{2} \mathrm{~N}^{-}\left(\mathrm{O}^{-}\right) \mathrm{NO}^{-} \rightarrow \mathrm{N}_{2}+2 \mathrm{OH}^{-}
\end{aligned}
$$

This formulation accounts for the two principal products, ammonia and nitrogen. It also accounts for the fact that nitrous oxide is obtained only in the later stages of the reaction. This product is formed as a consequence of the dimerization of nitrosyl anion.

$$
\begin{aligned}
& 2 \mathrm{NO}^{-} \rightarrow{ }^{-} \mathrm{ONNO}^{-} \\
& -\mathrm{ONNO}^{-}+2 \mathrm{H}_{2} \mathrm{O} \rightarrow \mathrm{HONNOH}+2 \mathrm{OH}^{-} \\
& \mathrm{HONNOH}+\mathrm{OH}^{-} \rightarrow \mathrm{N}_{2} \mathrm{O}+\mathrm{HOH}
\end{aligned}
$$

In the early stages of the reaction, $\mathrm{NO}^{-}$is scavenged by Reaction 4.32 , but as the concentration of the starting material is depleted, Reaction 4.33 becomes competitive and the byproduct, nitrous oxide, is formed. This is one of several branch points in which the product distribution is dictated by the rate constants for competing bimolecular reactions, and the differing concentrations of the reagents. The stoichiometry of the formation of hyponitrite from hydroxylamine in basic solutions has been given as (Nast and Foppl 1948; Barefield et al. 1996): 


$$
4 \mathrm{NH}_{2} \mathrm{OH}+2 \mathrm{OH}^{-} \rightarrow 2 \mathrm{NH}_{3}+\mathrm{N}_{2} \mathrm{O}_{2}{ }^{2-}+4 \mathrm{H}_{2} \mathrm{O}
$$

The half-life of $\mathrm{N}_{2} \mathrm{O}_{2}{ }^{2-}$ was reported by Ashby et al. (1992) to be 600 hours at $25^{\circ} \mathrm{C}$ in $1 \mathrm{M} \mathrm{NaOH}$. Since the $\mathrm{N}_{2} \mathrm{O}_{2}^{2-}$ anion decomposes predominantly to yield nitrous oxide, the ratio of nitrogen to nitrous oxide formed from the decomposition of hydroxylamine in alkaline solutions decreased with increased reaction time (Barefield et al. 1996).

The chemistry in the waste is much more complex because other substances also compete for these reactive intermediates, but the suggestion that nitrene is a reactive intermediate capable of hydride abstraction provides a convenient explanation, in the absence of other plausible alternatives, for the formation of ammonia from hydroxylamine.

\subsubsection{Ammonia from Cyanate Anions}

Ammonia can be formed via the decomposition of cyanate anion, $\mathrm{OCN}$. The cyanate ion can be formed in the wastes by the dehydration of the adduct of nitrosyl anion and formaldehyde:

$$
\mathrm{H}_{2} \mathrm{CO}+\mathrm{NO}^{-} \rightarrow \mathrm{ONCH}_{2} \mathrm{O}^{-} \rightarrow \mathrm{OCN}^{-}+\mathrm{H}_{2} \mathrm{O}
$$

Cyanate anion decomposes in both acidic and alkaline aqueous solutions to yield ammonia and carbon dioxide (Cotton and Wilkinson 1980). March (1992) suggests that the reaction presumably proceeds through the adduct shown in Reaction 4.38:

$$
\mathrm{OCN}^{-}+2 \mathrm{H}_{2} \mathrm{O} \rightarrow\left[\mathrm{H}_{2} \mathrm{NC}(=\mathrm{O}) \mathrm{O}^{-}\right] \rightarrow 2 \mathrm{CO}_{2}+\mathrm{NH}_{3}+\mathrm{OH}^{-}
$$

Urea is also listed as a decomposition product of the cyanate anion in aqueous solutions (Merck Index 1976). This compound is readily hydrolyzed in strong base to liberate ammonia. 


\subsection{Formation of Nitrous Oxide, Nitrogen, and Hydrogen}

Reaction sequences that result in the formation of ammonia often also lead to the formation of other nitrogenous products, particularly nitrous oxide and molecular nitrogen. Many examples of cogeneration of ammonia, nitrogen, and nitrous oxide have been described in preceding sections. Reaction sequences that favor the formation of nitrogenous gases circumvent the formation of hydrogen. The presence of oxygen can alter these reaction pathways to favor the formation of hydrogen and suppress the formation of nitrogenous gases. This aspect is discussed in more detail in Section 6.

Nitrosyl anion and its conjugate acid, HNO, appear to be very important initial products of the reduction of nitrite ion. They are formed in a variety of different oxidation reactions of the organic complexants as discussed in Section 3 . The nitrosyl anion readily dimerizes to give hyponitrite ion, $\mathrm{N}_{2} \mathrm{O}_{2}^{2-}$ (Cotton and Wilkinson 1980). This substance is well known to produce nitrous oxide.

$$
\begin{aligned}
& 2 \mathrm{NO}^{-} \rightarrow{ }^{\circ} \mathrm{ON}=\mathrm{NO}^{-} \\
& -\mathrm{ON}=\mathrm{NO}^{-}+2 \mathrm{H}_{2} \mathrm{O} \rightarrow \mathrm{HON}=\mathrm{NOH}+2 \mathrm{OH}^{-} \\
& \mathrm{HON}=\mathrm{NOH} \rightarrow \mathrm{N}_{2} \mathrm{O}+\mathrm{H}_{2} \mathrm{O}
\end{aligned}
$$

As already shown in Reaction 4.32, Barefield and coworkers (1996) have proposed that nitrosyl anion reacts with the salt of hydroxylamine in alkaline solution to yield molecular nitrogen. The reaction would proceed equally well between nitrosyl anion and hydroxylamine:

$$
\begin{aligned}
& \mathrm{NO}^{-}+\mathrm{HONH}_{2} \rightarrow \mathrm{H}_{2} \mathrm{NNO}+\mathrm{OH}^{-} \\
& \mathrm{H}_{2} \mathrm{NNO} \rightarrow \mathrm{N}_{2}+\mathrm{H}_{2} \mathrm{O}
\end{aligned}
$$

Only a few specific reaction pathways have been proposed for nitrogen formation in alkaline solutions. Van Der Puy and Dimmit (1985) have suggested that metal ions oxidize hydroxylamine and produce a radical, $\mathrm{H}_{2} \mathrm{NO}$, that dimerizes.

$$
\begin{aligned}
& \mathrm{H}_{2} \mathrm{NOH}+\mathrm{M}^{\mathrm{n}+} \rightarrow \mathrm{H}_{2} \mathrm{NO}+\mathrm{M}^{(\mathrm{n}-1)+}+\mathrm{H}^{+} \\
& 2 \mathrm{H}_{2} \mathrm{NO} \rightarrow \mathrm{NH}(\mathrm{OH}) \mathrm{NH}(\mathrm{OH}) \\
& \mathrm{NH}(\mathrm{OH}) \mathrm{NH}(\mathrm{OH}) \rightarrow \mathrm{N}_{2}+2 \mathrm{H}_{2} \mathrm{O}
\end{aligned}
$$

While there is relatively little information available on chemical pathways for the interconversion of nitrogenous gases and related ionic substances (e.g., $\mathrm{NO}^{-}$) in homogeneous solution free of potential inorganic catalysts, oxidation reduction reactions of nitrogen-containing ligands coordinated to transition metals have received considerable attention. Coordination of various nitrogen oxide fragments to transition metals have been studied extensively (Cotton and Wilkinson 1980). Compounds with coordinated nitrosyl ligands are in acid-base equilibrium with corresponding compounds with coordinated nitro ligands (Assefa and Stanbury 1997; 
MacNeil et al. 1997). This very active field of research has identified many rapid reactions involving organometallic catalysts, as illustrated in Reaction 5.9:

$$
c i s-\left[\mathrm{Ru}(\mathrm{bpy})_{2}\left(\mathrm{NH}_{3}\right) \mathrm{NO}\right]^{3+}+\mathrm{H}_{2} \mathrm{O} \rightarrow \text { cis- }\left[\mathrm{Ru}(\mathrm{bpy})_{2}\left(\mathrm{NH}_{3}\right) \mathrm{NO}_{2}\right]^{+}+2 \mathrm{H}^{+}
$$

Here, "bpy" refers to the ligand bipyridine. Via similar complexes, ammonia has been oxidized to coordinated nitrosyl in aqueous solution (Assefa and Stanbury 1997). Further, dinitrogen compound formation was observed from reactions of coordinated nitrosyl. Thus, through transition metal coordination complexes, the kinetics of certain nitrogen oxide reactions can be accelerated considerably over rates that could be achieved in homogeneous solution in the absence of these reagents. Van Der Puy and Dimmit (1985) have pointed out that the reactions occur in the absence of complex ligands, and since the Hanford wastes are known to contain iron, chromium, nickel, traces of many other potentially catalytic transition metals, and low concentrations of certain noble metals, these reaction pathways may also contribute to the formation of the nitrogenous gases. However, the observed chemical transformation would occur even in the absence of these catalysts.

Molecular hydrogen can be formed in Hanford wastes via reactions in which hydrogen atoms abstract a second hydrogen atom from an organic complexant or solvent. The hydrogen atoms are formed initially as a primary radiolytic product as well as by beta scission reactions of intermediate radicals. Such radical reactions are initiated by radiolysis at all temperatures. They are also initiated by the decomposition of certain waste components at relatively high temperatures (associated with a high activation energy). However, the yields of hydrogen atoms from the radiolysis of the salt rich Hanford wastes are small, and these reactive substances are also very rapidly scavenged in reactions with the inorganic constituents. Consequently, Meisel and his associates (1997) have concluded that little hydrogen is formed by this reaction path. Rather, they concur that hydrogen gas is formed in base-catalyzed ionic reactions as originally proposed by the GIT group (Section 3.2). Formaldehyde, other aldehydes, and the formate ion, which are obtained from various steps in the decomposition of complexants and solvents, are the most reactive and most important sources of hydrogen. The rates of these processes depend on the hydroxide ion concentration and possibly on the aluminate anion concentration. Thermodynamic arguments have been given to indicate that hydrogen may also be a product of the decomposition of hydroxylamine (Barefield et al. 1996). However, no detectable amounts of hydrogen were generated from this molecule under carefully controlled conditions. 


\subsection{Role of Oxygen}

Oxygen plays a novel role in the chemistry of Hanford wastes. While there are significant quantitative differences in the results obtained in different laboratories, recent reports (Barefield et al. 1995, 1996; Person 1996; Camaioni et al. 1996, 1997; Pederson and Bryan 1996) affirm that oxygen can have an important influence on the rate of decomposition of organic complexants and significantly alters the product distribution by increasing the relative rate of formation of hydrogen and sodium oxalate and decreasing the relative rate of formation of sodium formate and nitrogenous gases. The available data indicate that oxygen has essentially the same influence on thermal and radiolytic reactions. Some results and their consequences are examined in this section.

The potential impact of oxygen on the course of the reactions is highlighted in the Georgia Institute of Technology study (Barefield et al. 1996) of the decomposition of HEDTA at $120^{\circ} \mathrm{C}$. As shown in Table 6.1, two sets of experiments were conducted under argon and contrasted with the results obtained in the presence of oxygen. Measurements at other times and temperatures indicate the same general trends.

These data indicate oxygen slows the thermal and radiolytic conversion of organic complexants. Oxygen also decreases the yields of the three nitrogen-containing gases and reduces the consumption of the nitrite ion. Oxygen increases the rate of hydrogen formation significantly; this example indicates that hydrogen production is increased by a factor of 8 . Oxygen decreases the yield of the formate ion but increases the yield of the oxalate ion. As already mentioned, although the quantitative results differ, there is generally good agreement concerning the major features of the role of oxygen in gas generation (Barefield et al. 1995, 1996; Bryan and Pederson 1996; Camaioni et al. 1995, 1996; Person 1996).

The data indicate that the usual radiation-promoted, base-catalyzed disproportionation reactions, in which HEDTA is converted to oxidized substances that remain in the tank and hydrogen-rich gases that escape from the system, are shifted toward more highly oxidized organic products by oxygen, and there is a net decrease in the yields of reduced nitrogenous gases, specifically ammonia, nitrogen, and nitrous oxide.

Table 6.1. Products of Decomposition of 100 Moles of HEDTA after 200 Hours in Simulated Hanford Waste at $120^{\circ} \mathrm{C}$ (Barefield et al. 1996)

\begin{tabular}{|c|c|c|c|c|c|c|c|c|}
\hline Gas & HEDTA & ED3A & Oxalate & Formate & $\mathrm{H}_{2}$ & $\mathrm{~N}_{2}$ & $\mathrm{~N}_{2} \mathrm{O}$ & $\mathrm{NH}_{3}$ \\
\hline $\mathrm{Ar}$ & 42 & 46 & 4 & 75 & 1 & 11 & 32 & 40 \\
\hline $\mathrm{Ar}$ & 45 & 46 & - & 72 & 1 & 9 & 30 & - \\
\hline $\mathrm{O}_{2}$ & 86 & 7 & 8 & 15 & 8 & $<1$ & $<1$ & 4 \\
\hline
\end{tabular}


In view of the fact that oxygen in alkaline solution is known to convert alcohols into ketones and carboxylate anions (Lowry and Richardson 1987; Carey and Sundberg 1990; March 1992), the major change in the reaction pathway is not too surprising. But the finding that the dihydrogen yield increases by almost a factor of 10 (Barefield et al. 1996) may not have been anticipated.

Oxygen serves two roles: First, it intercepts the radicals and atoms that are produced in radiolytic and thermal reactions, converting them to new materials that possess higher oxidation potentials. For example, nitrosyl anion is converted to $\mathrm{ONOO}^{-}$(peroxynitrite), which rearranges to the nitrate anion (Stern et al. 1996). The lifetime for conversion of peroxynitrite to nitrite is approximately 1 second in near neutral (physiologic) solution, when dissolved oxygen is present (Fukuto and Ignarro 1997). Second, oxygen reacts directly with the reactive radical intermediates such as the radical formed in Reaction 3.2 to form a hydroperoxide, which is eventually converted into the keto carboxylate in oxidative processes in several steps as shown in Reactions 6.1 to 6.4 :

$$
\begin{aligned}
& \mathrm{A}+\mathrm{RN}\left(\mathrm{CH}_{2} \mathrm{CO}_{2}^{-}\right) \mathrm{CH}_{2} \mathrm{CH}_{2} \mathrm{OH} \rightarrow \mathrm{AH}+\mathrm{RN}\left(\mathrm{CH}_{2} \mathrm{CO}_{2}^{-}\right) \mathrm{CHCH}_{2} \mathrm{OH} \\
& \mathrm{RN}\left(\mathrm{CH}_{2} \mathrm{CO}_{2}^{-}\right) \mathrm{CHCH} \mathrm{CH}_{2} \mathrm{OH}+\mathrm{O}_{2} \rightarrow \mathrm{RN}\left(\mathrm{CH}_{2} \mathrm{CO}_{2}^{-}\right) \mathrm{CH}(\mathrm{OO}) \mathrm{CH}_{2} \mathrm{OH} \\
& \mathrm{RN}\left(\mathrm{CH}_{2} \mathrm{CO}_{2}^{-}\right) \mathrm{CH}(\mathrm{OO}) \mathrm{CH}_{2} \mathrm{OH}+\mathrm{H}-\mathrm{Donor} \rightarrow \\
& \quad \mathrm{RN}\left(\mathrm{CH}_{2} \mathrm{CO}_{2}^{-}\right) \mathrm{CH}(\mathrm{OOH}) \mathrm{CH}_{2} \mathrm{OH}+\text { Donor Radical } \\
& \mathrm{RN}\left(\mathrm{CH}_{2} \mathrm{CO}_{2}^{-}\right) \mathrm{CH}(\mathrm{OOH}) \mathrm{CH}_{2} \mathrm{OH}+\mathrm{O}_{2}+\mathrm{OH}^{-} \rightarrow \mathrm{RN}^{-}\left(\mathrm{CH}_{2} \mathrm{CO}_{2}^{-}\right) \mathrm{C}(\mathrm{O}) \mathrm{CO}_{2}^{-}+\mathrm{H}_{2} \mathrm{O} \\
& \mathrm{RN}\left(\mathrm{CH}_{2} \mathrm{CO}_{2}^{-}\right) \mathrm{C}(\mathrm{O}) \mathrm{CO}_{2}^{-}+\mathrm{OH}^{-} \rightarrow \mathrm{RNH}^{-}\left(\mathrm{CH}_{2} \mathrm{CO}_{2}^{-}\right)+\mathrm{O}_{2} \mathrm{COCO}_{2}^{-}
\end{aligned}
$$

The greater potential for oxidation is illustrated by the higher relative yield of oxalate ion and the lower relative yield of nitrogen-containing gases.

The increased amount of hydrogen that is formed in the reaction in the presence of oxygen is especially interesting. It is pertinent to note that 8 moles of hydrogen and 15 moles of formate ion are formed in the presence of air (see Table 6.1). If formate ion comes from the available formaldehyde, then the reaction pathway that leads to hydrogen in the presence of oxygen is about $50 \%$ efficient. Previous studies in less complex solutions have found that formaldehyde, sodium hydroxide, and sodium peroxide provide hydrogen with $100 \%$ efficiency (Abel 1956; Rodd 1965). It therefore seems reasonable to suggest that the role of oxygen in the alkaline solutions is to provide the same intermediate that is responsible for the formation of hydrogen from formaldehyde. As already discussed, Ashby and his associates $(1993,1994)$ proposed that the intermediate in the absence of oxygen was $\mathrm{H}_{2} \mathrm{C}\left(\mathrm{O}^{-}\right)_{2}$ and that the hydrogen was formed by the reaction of this dianion with water. It is necessary to account for the greater efficiency of this process in the presence of peroxides. The increased efficiency may be understood quite readily on the basis of the increased extent of the formation constants for the tetrahedral intermediates, Reactions 3.22 and 3.23. That is, other factors being equal, the equilibrium concentration of $\mathrm{H}_{2} \mathrm{C}\left(\mathrm{O}^{-}\right)(\mathrm{OOH})$ exceeds the equilibrium concentration of $\mathrm{H}_{2} \mathrm{C}\left(\mathrm{O}^{-}\right)(\mathrm{OH})$. It is well known that the $\mathrm{HOO}^{-}$anion is more nucleophilic than the $\mathrm{HO}^{-}$anion (Jencks 1969; March 1992). Perhaps even more important is the fact that the hydroperoxyl proton is a much stronger 
acid than hydroxyl proton by approximately four orders of magnitude. Consequently, there is a major advantage for the formation of the dianion, $\mathrm{H}_{2} \mathrm{C}\left(\mathrm{O}^{-}\right)\left(\mathrm{OO}^{-}\right)$, from which hydrogen is produced by the reaction with water.

The results of the laboratory investigations are in reasonable accord with the investigations of the waste. For example, laboratory work has established that the oxygenforming intermediate atoms and radicals produced during radiolysis are rapidly consumed (Meisel et al. 1991a, 1991b, 1992, 1993), and work with the waste has shown that the dioxygen content in the lower portions of the waste is small (Shekarriz et al. 1996). It is also known that freshly cored samples of Tank SY-101 waste react with oxygen (Person 1996). The thermal aging investigations (Barefield et al. 1995, 1996) and radiolytic aging experiments (Camaioni et al. $1995,1996,1997$ ) in the presence of air provide sodium carbonate and sodium oxalate as the most abundant products. The observations imply that the chemistry in the plausibly more oxygen-rich upper portions of the waste may differ from the chemistry of the waste in the oxygen-poor lower regions. But the concept has not been verified by analytical investigations of the composition of the waste.

In summary, oxygen can alter the course of thermal and radiolytic reactions. Hydrogen is formed more rapidly, and the organic products of the reactions are more completely oxidized than the products of the conventional reaction providing sodium oxalate rather than sodium formate. 


\subsection{Summary and Conclusions}

Ammonia is a common constituent of both SST and DST wastes at Hanford. Although the high electrolyte concentration lowers the solubility of ammonia relative to pure water, the solubility remains sufficiently high to allow large quantities of this product to be retained in the wastes. It has been estimated, for example, that Tank A-101 currently contains approximately 36,000 moles of ammonia distributed throughout 930,000 gallons of waste. Toxic in relatively low concentrations, ammonia also contributes to the flammability hazard.

There are several pathways by which ammonia is produced in Hanford wastes. The most important route is through the organic waste-induced reduction of the nitrite ion. Ammonia is produced after a series of reduction reactions involving several transient intermediates. The second most important route is by the liberation of ammonia from the nitrogen-containing complexants. Initial reactions yield such products as ED3A, NTA, and IDA and do not yield ammonia. However, further oxidation provides amines and eventually primary amides and nitriles capable of hydrolysis to ammonia. Direct reactions of hydrogen with either nitrous oxide or nitrogen are unimportant routes to ammonia in Hanford wastes. Thermal reactions between hydrogen and nitrogen require high temperatures and pressures to proceed; radiolytic yields for these reactions are quite low.

Nitrite ion reduction is important not only for the formation of ammonia but for nitrogen and nitrous oxide formation as well. The nitrite anion is the most kinetically active oxidant in Hanford waste tanks. Radiolytic reactions proceed through the initial formation of nitrogen dioxide and nitric oxide. Nitric oxide reacts to form oximes, and these compounds hydrolyze to form hydroxylamine, which is subsequently destroyed to provide ammonia and nitrogen. Other reactions produce the nitrosyl anion that dimerizes to the hyponitrite ion and provides an important pathway to nitrous oxide. Ammonia may be formed from cyanate anions produced via reactions of nitrosyl anion with formaldehyde. The hydrolysis of the cyanate ion eventually results in ammonia and formate ion generation.

Recent evidence suggests that the interconversion of various oxidation states of nitrogen is possible when coordinated to various transition metals. Assefa and Stanbury (1997), for example, studied the oxidation of ammonia ligands to nitrosyl in coordination complexes with ruthenium. Analogous complexes may be present in Hanford wastes, which contain certain noble metals, iron, chromium, nickel, and other transition metals.

The presence of oxygen alters the chemistry of both thermal and radiolytic reactions by two principal means. Oxygen intercepts radicals produced in thermal and radiolytic reactions that would otherwise eventually result in the formation of nitrogen, nitrous oxide, and/or ammonia. Oxygen may also react directly with complexants and intermediates to yield oxalate and other oxidized products. The result is that hydrogen yields are enhanced and nitrogenous products are suppressed. 


\subsection{References}

Abel E. 1956. "Mechanismus und Kinetik der Wasserstoffentwieklung aus Aklalishcher Losung von Formaldehyd und Wasswestoffperoxyd." Z. Physik. Chem. Neue Folge, 7:101.

Agnew SF, RA Corbin, TB Duran, KA Jurgenson, TP Ortiz, and BL Young. 1995. Waste Status and Transaction Record Summary (WSTRS) Rev. 1, WHC-SD-WM-TI-615, Westinghouse Hanford Company, Richland, Washington.

Agnew SF. 1995. Hanford Defined Wastes: Chemical and Radionuclide Compositions. LA-UR-2657 Rev. 2, Los Alamos National Laboratory, Los Alamos, New Mexico.

Agnew SF. 1996. Hanford Defined Wastes: Chemical and Radionuclide Inventories: $H D W$ Model. LA-UR-96-858 Rev. 3, Los Alamos National Laboratory, Los Alamos, New Mexico.

Agnew SF, RA Corbin, TB Duran, KA Jurgenson, J Fitzpatrick, BL Young, J Boyer, and TP Ortiz. 1997. Hanford Tank Chemical and Radionuclide Inventories: Hanford Defined Wastes (HDW) Model, Rev. 4. WHC-SD-WM-TI-615, Westinghouse Hanford Company, Richland, Washington.

Ashby EC, EK Barefield, CL Liotta, and HM Neumann. 1992. In "Hanford Tank Safety Minutes of the Tank Waste Science Panel Meeting, March 24-27, 1992," WW Schultz and DM Strachan, eds. PNL-8278, Pacific Northwest Laboratory, Richland, Washington.

Ashby EC, F Doctorovich, CL Liotta, HM Neumann, EK Barefield, A Konda, K Zhang, J Hurley, and DD Siemer. 1993. "Concerning the Formation of Hydrogen in Nuclear Waste: Quantitative Generation of Hydrogen via a Cannizzaro Intermediate." J. American Chemical Society, 115:1171.

Ashby EC, A Annis, EK Barefield, D Boatright, R Doctorovich, CL Liotta, HM Neumann, CF Yao, K Zhang, and NF McDuffie. 1994. Synthetic Waste Chemical Mechanism Studies. WHC-EP-0823, Westinghouse Hanford Company, Richland, Washington.

Assefa $Z$ and DM Stanbury. 1997. "Oxidation of Coordinated Ammonia to Nitrosyl in the Reaction of Aqueous Chlorine with cis- $\left[\mathrm{Ru}(\mathrm{bpy})_{2}\left(\mathrm{NH}_{3}\right)_{2}\right]^{2+}$." J. Am. Chem. Soc., 119:521-530.

Barefield EK, D Boatright, A Desphande, R Doctorovich, CL Liotta, HM Neumann, and S Seymore. 1995. Mechanisms of Gas Generation from Simulated SY Tank Farm Wastes: FY 1994 Progress Report. PNL-10822, Pacific Northwest Laboratory, Richland, Washington. 
Barefield EK, D Boatright, A Desphande, R Doctorovich, CL Liotta, HM Neumann, and S Seymore. 1996. Mechanisms of Gas Generation from Simulated SY Tank Farm Wastes: FY 1995 Progress Report. PNL-1 1247, Pacific Northwest National Laboratory, Richland, Washington.

Bottomley F and RC Burns. 1979. Treatise on Nitrogen Fixation. Wiley Interscience, New York, p. 50.

Bryan SA and LR Pederson. 1994. Composition, Preparation, and Gas Generation Results from Simulated Wastes of Tank 241-SY-101. PNL-10075, Pacific Northwest Laboratory, Richland, Washington.

Bryan SA and LR Pederson. 1995. Thermal and Combined Thermal and Radiolytic Reactions Involving Nitrous Oxide, Hydrogen, and Nitrogen in the Gas Phase; Comparison of Gas Generation Rates in Supernate and Solid Fractions of Tank 241-SY-101 Simulated Waste. PNL-10490, Pacific Northwest Laboratory, Richland, Washington

Bryan SA and LR Pederson. 1996. Thermal and Combined Thermal and Radiolytic Reactions Involving Nitrous Oxide, Hydrogen, Nitrogen, and Ammonia in Contact with Tank 241-SY-101 Simulated Waste. PNNL-10748, Pacific Northwest National Laboratory, Richland, Washington.

Bryan SA, LR Pederson, RD Scheele, and SR Adami. 1993. In Proceedings of the $4^{\text {th }}$ Annual International Conference on High Level Radioactive Waste Management, Vol. 2, p. 1348. American Nuclear Society, Las Vegas, Nevada.

Bryan SA, LR Pederson, CM King, SV Forbes, and RL Sell. 1996. Gas Generation from Tank 241-SY-103. PNNL-10978, Pacific Northwest National Laboratory, Richland, Washington.

Burger LL. 1995. Calculation of Reaction Energies and Adiabatic Temperatures for Waste Tank Reactions. PNL-8557 Rev. 1, Pacific Northwest Laboratory, Richland, Washington.

Buxton GV, WP Greenstock, WP Helman, and AB Ross. 1988. "Critical Review of Rate Constants for Reactions of Hydrated Electrons, Hydrogen Atoms, and Hydroxyl Radicals in Aqueous Solution." J Phys. Chem. Ref. Data, 17:513.

Camaioni DM, SA Samuels, WD Lenihan, SA Clauss, KL Wahl, and JA Campbell. 1994. Organic Tanks Safety Program Waste Aging Studies. PNL-10161, Pacific Northwest National Laboratory, Richland, Washington.

Camaioni DM, WD Samuels, SA Clauss, JC Lenihan, KL Wahl, JA Campbell, and WJ Shaw. 1995. Organic Tanks Safety Program FY95 Waste Aging Studies. PNL-10794, Pacific Northwest National Laboratory, Richland, Washington. 
Camaioni DM, WD Samuels, JC Linehan, SA Clauss, AK Sharma, KL Wahl, and JA Campbell. 1996. FY 1996 Waste Aging Studies. PNNL-11312, Pacific Northwest National Laboratory, Richland, Washington.

Camaioni DM, WD Samuels, JC Lenihan, AK Sharma, MO Hogan, MA Lilga, SA Clauss, KL Wahl, and JA Campbell. 1997. Organic Tanks Safety Program FY97 Waste Aging Studies. PNL-10794, Pacific Northwest National Laboratory, Richland, Washington.

Campbell JA, S Clauss, K Grant, V Hoopes, B Lerner, P Lucke, G Mong, J Rau, and R Steele. 1994. Flammable Gas Safety Program, Analytical Methods Development: FY 1993 Progress Report. PNL-9062, Pacific Northwest Laboratory, Richland, Washington.

Campbell J. A, RM Bean, KL Wahl, GM Mong, KE Wehner, AD Rice, RJ Day, DB Bechtold, BR Wels, RW Schroeder, JW Ball, BD Valenzuela, JM Fry, SL Fitzgerald, PP Bachelor, B Griffin, RK Fuller, AB Benally, and SM Parong. 1995. Waste Tank Organic Safety Project: Analysis of Samples from Hanford Tanks 241-C-102, 241-BY-108, and 241-C-103. PNL-10531, Pacific Northwest Laboratory, Richland, Washington

Campbell JA, KL Wahl, S Clauss, K Grant, V Hoopes, GM Mong, J Rau, and R Steele. 1996. Organic Tanks Safety Program, Advanced Organic Analysis: FY 1996 Progress Report. PNL-11309, Pacific Northwest Laboratory, Richland, Washington

Carey FA and RJ Sundberg. 1990. Advanced Organic Chemistry, Third Edition. Plenum Press, New York.

Carlson CD. 1997. Speciation of Organic Carbon in Hanford Waste Storage Tanks: Part 1. PNNL-11480, Pacific Northwest National Laboratory, Richland, Washington

Cotton FA and G Wilkinson. 1980. Advanced Inorganic Chemistry, $4^{\text {th }}$ Ed. John Wiley and Sons, New York.

Delegard CH. 1980. Laboratory Studies of Complexed Waste Slurry Volume Growth in Tank 241-SY-101. RHO-LD-124, Rockwell Hanford Operations, Richland, Washington.

Delegard CH. 1987. Identities of HEDTA and Glycolate Degradation Products in Simulated Hanford High-Level Waste. RHO-RE-ST-55P, Rockwell Hanford Operations, Richland, Washington.

Fukuto JM and LJ Ignarro. 1997. "In Vivo Aspects of Nitric Oxide Chemistry: Does Peroxynitrite Play a Major Role in Cytotoxicity?" Acct. Chem. Res., 30:149.

Huckaby J, H Babad, and D Bratzel. 1995. Headspace Gas and Vapor Characterization Summary for the 43 Vapor Program Suspect Tanks. WHC-SD-WM-ER-514 Rev. 1A, Westinghouse Hanford Company, Richland, Washington. 
Jencks WP. 1969. Catalysis in Chemistry and Enzymology. McGraw-Hill Book Co., New York.

Johnson GD. 1996. Evaluation of Recommendation for Addition of Tanks to the Flammable Gas Watch List. WHC-SD-WM-ER-594 Rev. 0, Westinghouse Hanford Company, Richland, Washington.

Johnson GD. 1997. Flammable Gas Program Topical Report. WHC-SP-1193 Rev. 2, Westinghouse Hanford Company, Richland, Washington

King CM, SA Bryan, and LR Pederson. 1997. Gas Generation from Tank 241-S-102. PNNL-11600, Pacific Northwest National Laboratory, Richland, Washington

Kubic WL Jr. 1996. Summary, Review, and Analysis of Data for Tank 241-A-101. WHC-SDWM-SAD-034 Rev. 0, Westinghouse Hanford Company, Richland, Washington, Appendix E. Leffler JE. 1993. An Introduction to Free Radicals. John Wiley and Sons, New York.

Los Alamos National Laboratory. 1994. A Safety Assessment for Proposed Pump Mixing Operations to Mitigate Episodic Gas Releases in Tank 241-SY-101. LA-UR-92-3196 Rev. 9, Los Alamos National Laboratory, Los Alamos, New Mexico.

Lowry TH and KS Richardson. 1987. Mechanism and Theory in Organic Chemistry, Third Ed. Harper and Row Publishers, New York.

MacNeil JH, PA Berseth, EL Bruner, TL Perkins, Y Wadia, G Westwood, and WC Trogler. 1997. "Mechanism of Nitrous Oxide Formation by Metal-Catalyzed Reduction of Nitric Oxide in Aqueous Solution." J. Am. Chem. Soc., 119:1668.

March J. 1992. Advanced Organic Chemistry: Reactions, Mechanisms, and Structure, $4^{\text {th }}$ Edition. John Wiley and Sons, New York.

Meisel D, H Diamond, EP Horowitz, CD Jonah, MS Matheson, MC Sauer, and JC Sullivan. 1991a. Radiation Chemistry of Synthetic Waste. ANL-91/40. Argonne National Laboratory, Argonne, Illinois.

Meisel D, H Diamond, EP Horowitz, MS Matheson, MC Sauer, JC Sullivan, F Barnabas, E Cerny, and YD Cheng. 1991b. Radiolytic Generation of Gases from Synthetic Waste. ANL-91/40, Argonne National Laboratory, Argonne, Illinois.

Meisel D, CD Jonah, MS Matheson, MC Sauer, JC Sullivan, F Barnabas, E Cerny, YD Cheng, and T Wojta. 1992. Radiation Chemistry of High Level Waste. ANL-91/40, Argonne National Laboratory, Argonne, Illinois. 
Meisel D, CD Jonah, S Kapoor, MS Matheson, and MC Sauer. 1993. Radiolytic and Radiolytically Induced Generation of Gases from Synthetic Wastes. ANL-93/43, Argonne National Laboratory, Argonne, Illinois.

Meisel D, A Cook, DM Camaioni, and T Orlando. August 31-Sept. 5, 1997. "Chemistry, Radiation, and Interfaces in Suspensions of Nuclear Waste Simulants." In Proceedings of the Joint International Meeting of the Electrochemical Societies, Paris, France.

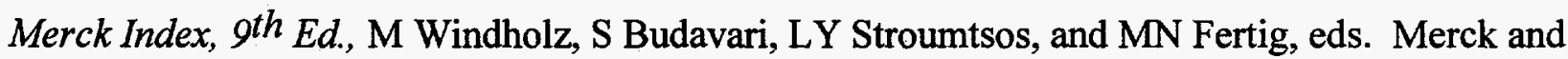
Co. Inc., Rahway, New Jersey.

Nast R and I Foppl. 1948. "The Formation of Hyponitrite by the Disproportionation of Hydroxylamine." Z. Anorg. Allgem. Chem., 256:159.

Norton JD and LR Pederson. 1994. Ammonia in Simulated Hanford Double-Shell Tank Wastes: Solubility and Effects on Surface Tension. PNL-10173, Pacific Northwest Laboratory, Richland, Washington.

Norton JD and LR Pederson. 1995. Solubilities of Gases in Simulated Tank 241-SY-101 Wastes. PNL-10785, Pacific Northwest Laboratory, Richland, Washington.

Pederson LR and SA Bryan. 1996. Status and Integration of Studies of Gas Generation in Hanford Waste. PNNL-11297, Pacific Northwest National Laboratory, Richland, Washington.

Person JC. 1996. Effects of Oxygen Cover Gas and NaOH Dilution on Gas Generation in 24ISY-101 Waste. WHC-SD-WM-DTR-043, Westinghouse Hanford Company, Richland, Washington.

Reszka KJ, P Bilski, and CF Chignell. 1996. EPR and Spin Trapping Investigations of Nitric Oxide from UV Irradiated Nitrite Anions in Alkaline Aqueous Solutions. J. Am. Chem. Soc., 118:8719.

Rodd I. 1965. Chemistry of Carbon Compounds, Volume I, Part C. Elsevier, Amsterdam, p. 18.

Shekarriz A, DR Rector, LA Mahoney, MA Chieda, JM Bates, RE Bauer, NS Cannon, BE Hey, CG Linschooten, FJ Reitz, and ER Siciliano. 1996. Preliminary Retained Gas Sampler Measurements for Hanford Waste Tanks 241-AW-101, A-101, AN-105, AN-104, and AN-103. PNNL-1 1450 Rev. 1, Pacific Northwest National Laboratory, Richland, Washington

Sorokin YA and SY Pshezhetskii. 1964. "Decomposition of Ammonia by Gamma Radiation." Russian J. Phys. Chem., 38(3):434-436. 
Spinks JTW, and RJ Woods. 1990. An Introduction to Radiation Chemistry. John Wiley and Sons, New York, p. 210.

Stern MK, MP Jensen, and K Kraner. 1996. "Peroxynitrate Decomposition Catalysts." J. Am. Chem. Soc. 118:8735.

Stock LM. 1992. Minutes of The Tank Waste Science Panel, WW Schultz and DM Strachan, eds. PNL-8274, Pacific Northwest Laboratory, Richland, Washington.

Su Z, DD Falvey, UC Yoon, and PS Mariano. 1997. "The Dynamics of Alpha-Anilino Carboxylate and Related Cation Radical alpha-Heterocyclic Fragmentation. J. Am. Chem. Soc. 11:5261.

Thomas JM and WJ Thomas. 1969. Introduction to the Principles of Heterogeneous Catalysis. Academic Press, New York, p. 408.

Van Der Puy M. 1985. Hydroxylamine. Redox Properties of Hydroxylamines Part 2. Organic Reactions,. Buffalo Research Laboratories, Allied Corporation, Buffalo, New York.

Van Der Puy M and JH Dimmit. 1985. Hydroxylamine. Redox Properties of Hydroxylamines Part 1. Inorganic Reactions. Buffalo Research Laboratories, Allied Corporation, Buffalo, New York.

Webb AB, JL Stewart, DA Turner, MG Plys, G Malinovic, JM Grigsby, DM Camaioni, PG Heasler, WD Samuels, and JJ Toth. 1995. Preliminary Safety Criteria for Organic Watch List Tanks and the Hanford Site. WHC-SD-WM-SARR-033 Rev. 0, Westinghouse Hanford Company, Richland, Washington. 


\section{Distribution}

No. of

Copies

Offsite

2 DOE/Office of Scientific and Technical Information

H. Babad

2540 Cordoba Court

Richland, WA 99352

E. K. Barefield

225 North Avenue

Boggs Chemistry Building

Georgia Institute of Technology

Atlanta, GA 30332

D. O. Campbell

102 Windham Road

Oak Ridge, TN 37830

C. W. Forsberg

MS-6495

P.O. Box 2008

Oak Ridge, TN 37831-6495

B. S. Hudson

Lawrence Livermore National

Laboratory, L-221

P.O. Box 808

Livermore, CA 94550

L. Kovach

NUCON

P.O. Box 29151

Columbus, OH 43229

T. S. Kress

102-B Newridge Road

Oak Ridge, TN 37830-8118
No. of

Copies

T. E. Larson

2711 Walnut St.

Los Alamos, NM 87544

2 Los Alamos National Laboratory

P.O. Box 1664

Los Alamos, NM 87545

Attn: S. Agnew

W. L. Kubic

D. Meisel

Argonne National Laboratory

9700 South Cass Avenue

Argonne, IL 60439

D. A. Powers

Sandia National Laboratories

MS 9744

P.O. Box 5800

Albuquerque, NM 87185-0744

W. W. Schulz

727 Sweetleaf Drive

Wilmington, DE 19808

S. E. Slezak

806 Hermosa NE

Albuquerque, NM 87110

Onsite

2 DOE Richland Operations Office

C. A. Groendyke

S7-54

G. W. Rosenwald

S7-54 
No. of

Copies

22 PHMC Team

S. A. Barker

G. S. Barney

W. B. Barton

R. E. Bauer

R. J. Cash

K. A. Gasper

D. L. Herting

G. W. Hood

T. A. Hu

J. R. Jewett

G. D. Johnson (4)

R. M. Marusich

J. C. Person

D. A. Reynolds

E. R. Siciliano

L. M. Stock

R. J. Van Vleet

J. R. White

N. E. Wilkins

No. of

Copies

44 Pacific Northwest National Laboratory

R2-11

T5-12

R2-12

S7-14

S7-14

H6-37

T6-07

S7-73

R2-11

T6-07

S7-14

A3-34

T6-07

R2-11

H0-31

S7-14

A3-34

S7-15

R2-12
Z. I. Antoniak

S. Q. Bennett

P. R. Bredt

J. W. Brothers (10)

S. A. Bryan

L. L. Burger

D. M. Camaioni

J. A. Campbell

C. D. Carlson

S. V. Forbes

P. A. Gauglitz

S. C. Goheen

R. T. Hallen

C. M. King

L. A. Mahoney

L. R. Pederson (10)

W. D. Samuels

R. D. Scheele

R. L. Sell

C. W. Stewart

J. M. Tingey

Information Release (5)
K7-15

K7-90

P7-25

K9-20

P7-25

P7-25

K2-44

P8-08

P7-25

P7-25

P7-41

P8-08

P8-38

P7-25

K7-15

K2-44

K2-44

P7-25

P7-25

K7-15

P7-25

K1-06 